\title{
TWO FUNDAMENTALS FOR FEDERAL PLEADING REFORM
}

\author{
WILLIAM L. EAgLeTON*
}

$\mathrm{T}$

HE YEAR I936 will probably witness a really important forward step in our law, the completion of new rules governing pleading and practice in the Federal courts. ${ }^{\mathrm{I}}$ It is extremely unfortunate that, during the drafting of these rules, ill health prevented the assistance of that great authority on pleading, Judge Edward W. Hinton. It is indeed ironical that the coming of the new year so propitious for pleading reform should coincide with the passing of this acknowledged master and discriminating admirer of the old and grand in pleading.

In pleading reform, the attitude of our respected teacher and beloved colleague was frequently misunderstood. Some thought that he was antagonistic toward all pleading reform. Actually he merely objected to the popular type of reform through an apparently revolutionary code.

To Judge Hinton, pleading was an art, developed to facilitate the trial of the case. Each ancient rule had its historical explanation. Some rules had outlived their usefulness; others had from the beginning been undesirable concessions to avoid punishing the unskilled. Desirable rules had been misunderstood and misapplied. Changes were needed. The courts should remember that pleading was a means toward an end: an orderly trial. Each rule should be re-examined to see if it still served that purpose; its application should be limited to the cases for which it was developed. The courts in the past had taken the lead in improving pleading, not by rules of court, but by constructive decisions and well-considered innovations. A complete revival of this attitude by the courts would lead to safe and fairly adequate reform. The legislature might speed the reform and supplement the efforts of the court by changing or restricting particular rules or furnishing new tools for the pleader.

According to Judge Hinton, the foundations of common law and equity pleading were sound, tested by centuries of use. The modern codes had made little impression on those foundations; few of the old rules had been materially altered except as they had, or should have been, improved in the non-code states. The vice of the codes was vague language used to ex-

* Professor of Law, University of Chicago Law School.

I See Clark and Moore, A New Federal Civil Procedure, 44 Yale L. J. 387 (1935); 21 Am. Bar Ass'n J. 746, 762 (1935). 
plain existing rules of pleading or proposed changes. Pleading needed a reform which would cause the courts to govern their decisions on pleading questions by the test of trial convenience rather than outlived or misunderstood rules. But instead of supplying that need, the codes shifted the test even farther from trial convenience and toward the mere interpretation of rules. The cases arising under the codes overlooked, in the discussion if not in the decision, the questions of practical utility. The entire attention of the courts seemed to be focused on their efforts to interpret the unintelligent rules containing such expressions as: "real party in interest," "a plain and concise statement," "facts," "cause of action," "persons having an interest in the subject of the action," "interest in the controversy," "transaction," "consistent with each other," "defenses .... legal or equitable," and "the distinctions .... and the forms .... have been abolished.",2

But the wave of reform by codes and rules is not to be stopped. Too many of the rules of equity pleading were influenced or controlled by the abandoned secret trial, or the decadent equity method of discovery. Common law pleading is too rigid in its joinder rules, and has degenerated into a tricky game with neither courts nor lawyers much interested in the object of trial convenience or in reform. These old systems of pleading are now unquestionably doomed. Codification, by statute or by rules of court, is here. It is too late to fight for less drastic reform. Objectors should concentrate their efforts on the elimination of the major faults to be found in present codes.

A careful study of existing codes and rules, with due consideration given to every suggestion, is particularly important while the new Federal rules are being drafted. The prominence of the United States Supreme Court, alone, will give great influence to the rules which it promulgates. In addition, the desire for uniformity, with the need of learning only one

" "The result is that under legislative codes in operation the practice has grown more complicated and technical. The time of the court is taken up in construing language that has no definite meaning, or else the court is hampered by language that is rigid and fixed. And in the end the rules are not what the legislature may have intended but what the courts have made out of the language of the statute by the slow process of construction." Hinton, Court Rules for the Regulation of Procedure in the Federal Courts, I3 Am. Bar Ass'n J., Part II, p. 8 (March, 1927).

Judge Finton's views on pleading reform were best expressed in the classroom. See Hinton, Stenographic Report of Lectures on Illinois Civil Practice Act (r934). His casebook on Code Pleading (3d ed. 1932) furnishes a clew to his attitude toward some of the vague provisions in the codes. His most important law review contributions in this field are:

Equitable Defenses under Modern Codes, 18 Mich. L. Rev. $7 \times 7$ (1920); An American Experiment with the English Rules of Court, 20 Ill. L. Rev. 533 (I926); Pleading under the Illinois Civil Practice Act, I Univ. Chi. L. Rev. 580 (I934). 
system, will cause the lawyers of each state to urge the adoption of the new Federal rules for the state courts, so far as applicable.

Now is the time to re-examine carefully our old systems of pleading with the object of retaining the best and eliminating the undesirable features.

Two suggestions are here submitted: (I) The principal fault of common law pleading has not been clearly attacked nor entirely eliminated by existing codes. (II) The terminology of the codes has suffered from a lack of distinction between definite and indefinite terms.

\section{I}

A. PENALTIES IN COMMON IAW PLEADING

The principal fault of common law pleading lay in the penalties imposed for a breach of the rules. The classical penalty was final judgment against the client of the lawyer who erred in pleading. Whether this was the result of a considered scheme for forcing compliance with the rules, or was merely another example of the formalistic tendencies of the time, ${ }^{3}$ is immaterial. The courts of the seventeenth and eighteenth centuries seemed to delight in giving judgment on the pleadings. At an earlier time, the trial itself, as by wager of law, was not efficient or fair in determining the facts, so that a judgment based on a pleading error was perhaps not seriously objectionable. But the courts have persisted in giving judgment on the pleadings even in modern times. This practice of imposing the penalty of judgment for an error in pleading deserves severe condemnation, even though it may be true that this technical justification for the judgment is often either a make-weight, or an excuse to avoid deciding a difficult dispute on the merits.

The imposition of this severe penalty for an error in pleading had two unfortunate effects on common law pleading:

I. There was a marked tendency to develop definite rather than flexible rules. As will be shown in the discussion of definite and indefinite terms in the codes, there is often need for a flexible rule, based on trial convenience. ${ }^{4}$ The trial court should be given much discretion in guiding the pleadings so as to prepare the case for trial. For instance, joinder of separate causes of action might well be left to the court's determination of whether or not a combined trial would be more convenient than separate trials. But a penalty of final judgment should not be imposed because a

3 Pound, Some Principles of Procedural Reform, 4 Ill. L. Rev. 388, 396 (Igro).

4 Part II infra. 
lawyer failed to guess the decision of a court guided only by such an indefinite rule. If the penalty is to be severe, the rule must be definite. ${ }^{5}$ On the other hand, the definite rule, based on only a few of the facts and ignoring all others, will reach undesirable results in many cases. Thus the severe penalties lead to definite rules, and the definite rules of common law pleading have received and deserved the epithet of "technical."

2. Undesirable technical rules and exceptions were often made in order to avoid the imposition of harsh penalties. Such technicality is the common result of excessive penalties. The effect of capital punishment on the law of the crime of larceny is the classical example. But the technicalities limiting larceny because of the severity of the punishment were minor, at least in quantity, as compared with the many rules and exceptions developed by the courts in the field of pleading to justify the refusal to impose a penalty. ${ }^{6}$

Pleading reformers have disliked the cases rendering judgment because of errors in the pleading. ${ }^{7}$ But the usual remedy has been an attack on the rule that was violated, rather than on the penalty. The most publicized illustration is the present popularity of "notice pleading." of the objects of pleading. It and other objects' ${ }^{9}$ have guided the development of present rules of pleading. An added emphasis on this one object might lead to changes in our present rules. But this slightly different emphasis would not change the methods of objecting to pleadings that violate the amended rules, nor abolish the penalty of judgment for such violation. In fact the rules prescribing "notice pleading" would make that penalty more unjust, as violations would be less censurable during the periods of change, especially since the new rules would probably be less

5 Freund, The Use of Indefinite Terms in Statutes, 30 Yale L. J. 437, 439-444 (I921); Freund, Legislative Regulation, 240 ff. (I932). The teachings of Professor Freund were the controlling influence on the writer (though this influence was not realized at the time) in Eagleton, The New Minnesota Probate Code, 20 Minn. L. Rev. I, 3-8 (I935).

${ }^{6}$ Compare, on the other hand, the development of technical rules in defamation cases, apparently with the sole object of enabling the court to give judgment against the plaintiff on the pleadings in those cases so unpopular with the courts at the time. Cook and Hinton, Cases on Common Law Pleading 3r4-336 (r923).

7 For a clear understanding of this, with a suggestion that the remedy lies in greater liberality in allowing amendments, see Scott, Fundamentals of Procedure in Actions at Law I66 (I922).

8 Whittier, Notice Pleading, 3 I Harv. L. Rev. 50 I (I9I8); Pound, Some Principles in Procedural Reform, 4 Ill. L. Rev. 49r, 497 (Igro); Pound, A Bibliography of Procedural Reform Including Organization of Courts, Ir III. L. Rev. 45I (19I7); Clark, Code Pleading 29, note 94 (r928).

9 Isaacs, Logic v. Common Sense in Pleading, I6 Mich. L. Rev. 589 (Igr8). 
definite than the old ones. The demand for which notice pleading is an unsatisfactory answer is really a demand that the party should not be severely punished because his lawyer in a pleading omitted a material fact or failed to state it in the prescribed language. ${ }^{x 0}$ How much better an answer would be a re-examination of the pleading rules to see that they best serve all the objects of pleading and then an imposition of only a reasonable penalty if the rules are not followed!

The difference between these two attitudes is so important that further illustrations should be given.

In common law pleading, as well as in other systems seeking to develop issues for trial, pleadings continue until an issue is reached. An issue of "fact" is reached where an allegation is affirmed by one of the parties and denied by the other. It has seemed desirable to require the party raising this issue to state his denial in a form that will clearly indicate his belief that a material issue is reached and further pleadings are unnecessary. As far as notice is concerned, an argumentative denial or alibi, stating facts inconsistent with the allegation to be put in issue, is superior to a direct denial in that it discloses the plans for disproving the allegations. But in form, the argumentative denial resembles an affirmative pleading and is apt to mislead the opponent into continuing the pleading, perhaps with a departure and at best a traverse which would seem to raise the issue of the truth of the argumentative denial rather than the truth of the original allegation which should have been put in issue. Argumentative denials should be discouraged. The offense is perhaps serious enough to warrant the imposition of a five dollar or ten dollar fee for the privilege of amending. Certainly final judgment on a demurrer to such a pleading would be excessive. And after a trial on the merits, the pleader should be entitled to a judgment in accordance with the merits in spite of his error in pleading. Yet there are cases, both at common law and under the codes, where even an appellate court has grounded its decision on the presence of an argumentative denial in a plea or replication..$^{\mathrm{Ix}}$ Such cases are to be condemned. But what should be the nature of this condemnation? The tendency among pleading reformers has been to criticize the rule banning argumentative denials or to insist that "argumentativeness should be regarded as a defect only so far as it actually makes uncertain what allegations the

ro 'This was recognized by Stephens. See Stephens, Pleading 492 (Andrews' 2d ed. Igor). However he offers no real remedy. His defense is in mitigation rather than in bar: "Yet is their inconvenience less severely felt in practice at the present day, than a mere theoretical acquaintance with the subject would lead the student to suppose."

II For cases see Clark, Code Pleading 402, notes 48 and 50 (rg28). 
answer is denying." 22 That attitude is doubly undesirable. In the first place, argumentative denials should be discouraged by the imposition of reasonable penalties even when they do not mislead the opponent. In the second place, the severe penalty of final judgment should not be imposed even when the opponent claims to have been misled.

The negative pregnant is another objectionable traverse. At its best, ${ }^{13}$ it is ambiguous or duplicitous; at its worst, ${ }^{\mathrm{I}}$ construed most strongly against the pleader by emphasizing the grammar or logic rather than the clearly intended meaning, it may be interpreted as merely denying an immaterial allegation. The negative pregnant, like the argumentative denial, might fairly be discouraged by the imposition of a reasonable penalty. But again the courts, even in the code states, often impose the penalty of judgment on the pleadings. ${ }^{15}$ And again those opposed to these cases attack the substance of the rule with the suggestion that the pleadings should be considered defective only when "the pleading is indefinite and uncertain." 16 It is submitted that in this and other similar cases $^{17}$ the fault lies, not with the substance of the rule condemning negative pregnants or other undesirable pleadings, but rather with the imposition of the unreasonable penalty of judgment on the pleadings.

\section{B. METHODS FOR REFORM}

If this theory is correct, how should the rules of pleading be changed so as to modernize and liberalize the penalties? To answer that question, it is necessary to examine the rules and procedures which now produce the

${ }^{2}$ Clark, Code Pleading 402 (1928). Compare: "Express admissions and denials must be direct and specific, not argumentative." Rules of Civil Practice, art. I5, $\$ 25$, Am. Jud. Soc. Bull. XIV, 64 (I9I9).

${ }_{3}$ If a plea denies a combination of two material allegations in the declaration, it is uncertain whether it is denying one, or the other, or both. In any of these cases, the denial of the combination is true. However, since each allegation is material, the plea unequivocally claims the existence of at least one good defense; the fault is that the plea does not unequivocally state which defense exists. See Stephens, Pleading 346 ff. (Andrews' 2d ed. I90I).

${ }^{2}$ In the usual case of a negative pregnant, the denial is of a combination of a material allegation and an immaterial allegation. Again there is uncertainty, and the denial is true if only the immaterial allegation is disproved. Construing the denial against the pleader, it is taken to deny only the immaterial allegation, admitting the material one. See cases cited in Clark, Code Pleading 399 (1928).

is Clark, Code Pleading 4or, note 45 (1928).

${ }^{16}$ Clark, Code Pleading 400, $40 \mathrm{r}$ (I928). Compare the rule barring the negative pregnant in Rules of Civil Practice, art. I5, \$ 30, Am. Jud. Soc. Bull. XIV, 65 (I9I9).

${ }^{27}$ In the recent case of Randall Dairy Co. v. Pevely Dairy Co., I78 Ill. App. 350 (I935), two causes of action were erroneously included in one count, and this minor error was relied upon by the appellate court as a ground for reversal, in spite of the "spirit" of the new Civil Practice Act. 
obnoxious penalties. All the rules should be carefully studied to make sure they reflect the desired emphasis on pleadings as aids to the trial rather than pitfalls for the unwary. ${ }^{x 8}$ In particular, the methods of objecting to defects in pleadings should be most thoughtfully examined, and the rules most thoroughly prescribed both as to the errors that can be reached by each objection and as to the effect of the ruling on the objection. These will be here discussed under the headings: ( $I$ ) objections raised during the pleading stage; (2) objections during the trial stage; and (3) objections after trial and on appeal. Following this discussion, an attempt will be made to state proposed rules which will carry out the suggestions in these limited fields.

\section{Objections Raised During the Pleading Stage}

Two devices were developed in common law pleading for raising objections to the opponent's pleadings during the pleading stage, the demurrer and the motion.

In theory the demurrer was similar to the negative plea or other traverse. Each raised an issue, and the determination of that issue was to settle the case for one party or the other. The negative plea denied one of the material allegations of "fact" in the declaration; the demurrer denied the implied allegation that the "facts" in the declaration constituted a good prima facie cause of action. The traverse raised an issue of "fact"; the demurrer raised an issue of "law." I9 The issue raised by the plea was ordinarily tried by a jury; the issue raised by the demurrer was tried by the court without a jury. In either case, the decision of that issue resulted in a final judgment.

The motion, on the other hand, mentioned the error in the previous pleading and as a rule merely asked that the error be corrected. The ruling on the motion did not result in a final res adjudicata judgment. It is true that a final judgment could be obtained if the losing party wished to appeal; the order requiring an amendment or pleading over would be ignored, resulting in a dismissal or a judgment by default nil dicit. But the theory of the motion did not call for the imposition of final judgment

\footnotetext{
${ }^{8}$ This applies to rules of practice as well as rules of pleading. Thus: (a) A failure to file an answer within the time allowed should not make the answer a nullity when filed late; the answer should prevent the taking of a default judgment after the answer was filed. Flanders $v$. Whittaker, 13 Ill. 707 (I852); Walter Cabinet Co. v. Russell, 250 IIl. 4I6, 95 N.E. 462 (I9II); Farmer v. Fowler, $288 \mathrm{Ill} .494$, x23 N.E. $55^{\circ}$ (rgIg). (b) When a cause of action has been improperly split, the payment of one judgment should not bar the other action if the plaintiff is willing to pay the costs of the first action. (c) An appeal should not be absolutely barred because of a failure in one formal step in the appeal.
}

s9 Compare Stephens, Pleading 482 (Andrews' 2d.ed. r9or). 
against the pleader making the error, nor against the party filing a motion that was overruled.

The equity demurrer to the bill was similar to the common law motion, and merely asked the judgment of the court, whether the defendant should be compelled to answer the bill or not. In case the demurrer was sustained, the defendant was excused from answering unless and until the bill was made legally sufficient. When the demurrer was overruled, the defendant was required to answer or plead. ${ }^{20}$ The ruling was not a final decree, but an appealable ruling could be obtained as in the case of the common law motion. ${ }^{2 x}$

In equity pleading, the demurrer was used only in raising objections to the bill; an answer was attacked by an "exception," 2 and a plea was "set down for argument" without the filing of a formal pleading. ${ }^{23}$ In either case, the theory and ruling were similar to those of the motion and the equity demurrer. ${ }^{24}$

While the theory of the common law demurrer, calling for a final judgment, was quite different from that of the motion or the objections in equity, the difference very nearly disappeared in practice during recent times, starting when the court became very liberal in permitting the overruled demurrer to be withdrawn (with plea filed) or the defective pleading to be amended..$^{25} \mathrm{~A}$ final judgment and appeal is now probably as unusual after the argument on a common law demurrer as after the argument on a motion, or objection in equity. True, the attitude of the average court toward the common law demurrer may perhaps be a little more formal; nevertheless the distinction is not worth keeping, especially in view of the difficulty of drawing the line between the serious objections to be raised by demurrer and the minor objections to be raised by motion. ${ }^{26}$

${ }^{20}$ Langdell, A Summary of Equity Pleading I04 (2d ed. 1883); Smith v. Ballantyne, to Paige (N.Y.) ror (I843), Hinton, Cases on Equity Pleading 263 (I927).

${ }_{2 x}$ McDowell v. Cochran, II Ill. 3 I (1849), Hinton, Cases on Equity Pleading 264 (I927).

${ }_{22}$ Langdell, A Summary of Equity Pleading 87 (2d ed. 1883 ). The practice of setting the case down for hearing on bill and answer $(i d ., 88)$ should perhaps be omitted from this discussion, though it is a method of raising the question of the legal sufficiency of the answer, and may be compared to the common law demurrer.

${ }^{23} \mathrm{Id}$., at rog. $\quad{ }^{44}$ The effect of the ruling will be discussed p. 388 infra.

${ }^{25}$ Scott, Fundamentals of Procedure in Actions at Law 143 fr. (1922).

${ }^{26}$ Two illustrations should be sufficient to indicate that the line between the objection to be made by motion and the objection to be made by a demurrer is purely arbitrary: (I) In equity, an objection to an interrogatory is made by demurrer. Story, Equity Pleading (6th ed. I857) 505. (2) To get a more detailed statement of the cause of action at law, a motion for a bill of particulars is used in general assumpsit, while a special demurrer is used in an action on the case for negligence. 
Recent practice acts indicate the pleading reformers are in close agreement to the effect that only one type of pleading instrument should be used to raise objections as to the form and legal sufficiency of the preceding pleading, and that instrument should be called a motion. ${ }^{27}$ Though this does not produce very material change in pleading, the uniformity in terminology, theory, and procedure is all to the good.

But while there is agreement on the use of the name "motion," the question of the penalty accompanying the ruling on this motion has been largely overlooked.

a) Penalties Imposed with Ruling on the Motion.-The demurrer or motion raises an objection to a defect that "appears on the face" of the previous pleading. According to the objection, there has been a failure to carry out the pleading rules, as to a matter either of substance or of form. If the objection is sound, ${ }^{28}$ the defective pleading will fail to produce the desirable results for which the rule was developed; we should encourage the raising of the objection so as to correct the defect in this case and to discourage such defects in other cases. If the objection is not sound, we should discourage the raising of such unfounded objections.

As a general rule today, when ruling on a motion or demurrer the court imposes no penalty to discourage defective pleadings and unfounded objections or to encourage sound objections. The objection to a defective pleading, by motion or demurrer, merely educates the opposing attorney. It is ordinarily foolish to raise the objection, except for the unworthy purpose of stalling for time. Perhaps it is hoped that the same objection can be raised at a later stage, when a penalty will be imposed. At least it can

27 Cahill's New York C.P.A. $\$ 277$ (6th ed. I93I), Rules Io2-II2; Illinois C.P.A. $\$ 45$, Smith-Hurd's Ill. Rev. Stat. I935, c. IIo, § I69; Fed. Eq. Rule 29. In the Rules of Civil Procedure, Am. Jud. Soc. Bull. XIV (I9I9), motions are used for objections to certain minor defects (art. $16, \S \S x-3$ ), but an "objection in law" is used when the claim or defense is alleged to be invalid in law (art. $16, \S \S 7-10$ ). In particular, see comment to $\S 7$. The objection may validly be made that for some purposes it may be desirable to distinguish between objections to substance and objections to form (but see note 26 suppra); also the name "motion" is given to other requests for interlocutory or final orders, and the rules here suggested do not apply to such motions. While the confusion in vocabulary may cause some misunderstandings, the modern tendency in pleading is against the use of labels to distinguish between the various types of pleadings. Thus there is a tendency not to distinguish in the heading between pleas in abatement and pleas in bar, or between legal and equitable matter. The object of the confusion seems to be to break down undesirable barriers to uniformity in treatment. The validity of the policy, or of its application in certain cases, may be open to question. See McCaskill, One Form of Civil Action, But What Procedure, for the Federal Courts, 30 Ill. L. Rev. 415 (r935).

${ }^{28}$ That is, it is true (as alleged in the demurrer or motion) that a rule was violated by the pleading objected to. Of course we presuppose the rule was a desirable one developed to facilitate the trial; if not a desirable rule, it should be abolished. 
be hoped that the opponent will remain ignorant and make a serious mistake in the trial. As a result of this attitude, defective pleadings remain on the record and fail in their purpose of preparing the case adequately for trial.

If the rules of pleading are sound, they deserve sanctions which will force their observance. True, the common law penalty of final judgment was too severe. But more intelligent penalties have been used, and should be prescribed. Costs of the demurrer were often allowed in equity.92 In English practice, costs assessed for defects in pleading play an important part, perhaps too important a part, in most cases. ${ }^{30}$ In New York, costs have proven effective in enforcing rules of pleading. ${ }^{3 \mathrm{x}}$ It is not claimed that the imposition of costs is universally popular, for indeed no penalty is popular with the person against whom it is imposed; yet it can hardly be disputed that, on the one hand, the imposition of final judgment is too severe a penalty, and, on the other hand, pleading rules without sanctions will not be carried out. ${ }^{32}$

In the new Federal rules, the imposition of reasonable costs for the violation of a rule or for the filing of an unfounded motion should be encouraged by express edict. Even a small fee as costs should have a strong effect in discouraging poor pleading. Until the bar has had some experience with the new rules, these costs should certainly be limited in amount. Probably some discretion should be given the individual circuits to conduct experiments with more detailed rules governing costs, or additional limitations on their amount.

The rules imposing costs must take into consideration two special situations. First, a quite general pleading, such as the common counts in general assumpsit, may be permitted as adequate, with a bill of particulars ordered only if requested by motion; the pleading is not really defective and no penalty should be imposed if an adequate bill of particulars is willingly given. Second, even when a pleading is really defective, the pleader may be willing to correct the defect without arguing the motion. In this second case, there is some justification for the imposition of the penalty as the error has inconvenienced the party who has prepared the motion that educated the erring pleader. However, it is probably desirable to dis-

${ }^{29}$ Langdell, Summary of Equity Pleading ro5 (2d ed. I883).

${ }^{30}$ Higgins, English Courts and Procedure, Am. Jud. Soc. Bull. XI, 56, I02, 107 (Igr6).

3x Cahill's New York C.P.A. § I505 (6th ed. I93r).

32 For an unusual argument that if sanctions are not applied, "such objections will tend to lapse into disuse," and this will in some nebulous manner produce an improvement in pleading, see Pound, Some Principles of Procedural Reform, 4 Ill. L. Rev. 388, 402 (IgIo). Compare Higgins, supra note 30 . 
courage the common practice of contesting the motion even though it is clearly sound. This can be done, at the same time taking care of the motion for a bill of particulars, by providing in the rules that no costs shall be assessed if the defect objected to is promptly removed or the relief requested in the motion is adequately supplied.

b) The Ruling on the Motion.-There are many different types of objections that may be taken by motion. Each motion indicates the type of ruling deemed appropriate if the motion is sustained. The objection may go to the merits of the cause of action or defense, asking that the pleading be stricken in whole or in part, or even that judgment be given on the pleadings. In some cases this objection is so fundamental that it can not be eliminated by an amendment, but usually an additional allegation will cure the defect. Even in those objections to the merits, the ruling should permit an amendment, a final judgment to be rendered only on failure to eliminate the error by amendment. This is doubly important because the motion will often ask for judgment when the defect is merely one of form. Other objections going to the form of the pleading will properly ask for an order less drastic than judgment on the pleadings; as, that an allegation be stated in more detail (e.g., a bill of particulars), or that a pleading be made more definite and certain, or that duplicitous pleadings be separately stated, or that improperly joined causes of action involving the same or different parties be separated, or that immaterial matter or an unsubstantial pleading be stricken, or that improper parties be dropped or necessary parties be added. If the motion is overruled, the party should be ordered to plead over.

These rulings on the motions should ordinarily be interlocutory, and as such not the subject of immediate appeal without special leave of court. ${ }^{33}$ However, the party adversely affected by the ruling can stand on his pleading, in which case a final appealable judgment should be given on the pleadings. This judgment may differ in form, but not in substance, from the judgment of dismissal or by default nil dicit for failure to amend when the motion has been sustained or for failure to plead over when the motion has been overruled.

Thus far little difficulty has been met as only the broad general fundamentals of the motion have been stated: assuming the new pleading rules

${ }_{33}$ This problem of appeal is not within the scope of this paper, and may not be within the scope of the rule-making powers granted by the recent act. That the ruling is usually treated as interlocutory and not the subject of an immediate appeal, see ${ }_{4}$ C.J. 680 (Igr6). But the court should have power to grant leave to appeal when such appeal might settle the case in the most expeditious manner. See Art. 4I, § 4, Rules of Civil Procedure, Am. Jud. Soc. Bull. XIV, I80, I8I (rgrg). 
to be sound, they will be enforced by the use of motions raising objections to defective pleadings; such well-grounded motions will be encouraged by the habitual assessment of reasonable costs rather than by the occasional imposition of a final judgment; after the ruling on the motion, the losing party will ordinarily abandon his position and submit to the interlocutory order improving the pleadings; only in the unusual case will he stand by his position, allowing a final judgment to go against him. When the losing party stands by his position, the further problems as to the possibility of an appeal and the effect of the judgment likewise present little difficulty. The final judgment may of course be appealed. An affirmance on appeal will finally settle the case, with no opportunity left open for then abandoning the position and amending or pleading over. ${ }^{34}$ But a reversal on appeal should result in a remanding for the interlocutory order (for an amendment or pleading over) that would have been given if the lower court had properly ruled on the motion. ${ }^{35}$

When the losing party on the motion abandons his position and amends or pleads over, the problems connected with the appeal and the effect of the ruling are not correspondingly simple, but are technical and rather difficult. First, when can an exception to the ruling, with an appeal, be taken by the losing party (though he amends or pleads over)? Second, what effect will the ruling have on the trial of the action on the amended pleading?

c) Appeal of the Ruling on the Motion. - If the losing party amends or pleads over, for the purpose of raising other theories of recovery or defenses or for the purpose of raising the same matter in the manner prescribed by the order, he will probably never be substantially prejudiced if he is denied the right to appeal the ruling. If the objection merely affected the form of the pleading, an error in the ruling will do no harm that should call for a reversal. ${ }^{36}$ If the objection raised an issue regarding the substantive law to be applied in the case, the same question can ordinarily be raised during the trial ${ }^{37}$ by an objection to an instruction given or re-

34 McAlister v. Clark, 33 Conn. 253 (I866), Cook and Hinton, Cases on Common LawPleading 239 (I923); 4. C. J. II46, notes 48 and 50 (Igr6); Bailey v. Holden, 50 Vt. I4, 22 * ( 1877 ). This rule was recognized, but not applied because of the harshness of the result in the particular cases, in Gammon v. Bunnell, 22 Utah 421, 64 Pac. $95^{8}$ (I900); Keaton v. Little; 34 F. (2d) 396 (C.C.A. Ioth 1929 ).

35 Barre v. Daggett, ro5 Tex. 572, r53 S.W. rio (r9r3).

${ }^{36}$ This is well settled, though the line between "substance" and "form" is not a definite" one. If prejudice would result from the ruling, the matter would not be called merely one of "form." For lists of cases and specific objections, see 4 C. J-929, 930'(1916).

${ }^{37}$ The objection during trial will not be extensively argued, as the trial court will ordinarily 
fused, or to the findings of the court, or perhaps to the admission of some items of evidence, and an appealable exception can be taken to that ruling if it is adverse..$^{38}$ Thus the losing party is entitled to a fair trial. After such a fair trial on the merits, he should not be granted a new trial merely because of an erroneous adverse ruling during the pleading stage. ${ }^{39}$ It follows $a$ fortiori that the defective pleading should not furnish the grounds for an objection after a fair trial when no objection was made during the pleading stage. ${ }^{40}$

d) The Effect of the Ruling on the Motion.-As just indicated, the ruling that is not immediately appealable should not affect the substantive rights of the parties in such a way as to prevent either party from having a fair trial on the merits. This seems to be a necessary rule in view of the last mentioned rule denying an appeal of the ruling on the motion itself. Together these two rules state a fair plan toward which pleading reforms have been working. They are in keeping with a third rule, hereinafter discussed, abolishing motions in arrest of judgment and for judgment non obstante veredicto for defects in pleadings, the idea of all three rules being that the pleadings have served their purpose at the trial, and judgment

follow the substantive law theory developed for the ruling on the motion. But this should not prevent the making of objections for the purpose of getting rulings which will permit the theory of the trial court to be questioned on appeal.

${ }^{38}$ This would always be possible when the motion is overruled, if the pleader relies on that matter at the trial, as there could be objections to both evidence and instructions. If the motion is sustained, the pleader might amend by using two counts (or pleas or other pleadings as the case may be), retaining the old one for the purpose of appeal and adding a new one following the theory approved in the ruling or setting up any additional or substitutional cause of action or defense which the pleader may wish to rely on. See note 74 infra.

$39 \mathrm{Now}$, the appeal would generally be taken on the ruling on the demurrer. Where that ruling prescribes a theory of substantive law for the case, it might be argued that an appeal on that ruling would be as direct and intelligent as an appeal on the similar objection made during the trial. The answer seems to be that the ruling might prove absolutely harmless, as the ground raised in the pleading may not be raised during the trial; in this case, the nonprejudicial ruling should not be grounds for appeal. A rule that non-prejudicial error shall not be cause for a reversal would perhaps not prove effective, as the courts have too often said prejudice will be presumed from error in rulings of the trial court sustaining or overruling demurrers to pleadings or striking out pleadings (4 C.J. 9r 2 (IgI6)). If the burden of showing prejudice is placed on the appellant and the courts really carry out that mandate, the same result as here proposed would be achieved by the indirect method of an appeal on the pleading ruling, with proof of the objection at the trial to show prejudice. The proposed rule seems more certain of reaching the desired result, and is simpler in prescribing a direct appeal on the ruling on the objection at the trial, ignoring the ruling during the pleading stage.

$4^{0}$ The modern tendency in this direction is conspicuous in criminal cases as well as civil cases. Defects that might in the past have been successfully raised by a collateral attack (habeas corpus) or on direct appeal may now not even be the basis for an appeal. 24 IIl. Bar. J. I65 (I936), commenting on People ex rel. Merrill v. Hazard, 36I Ill. 60, I96 N.E. 827 (I935). 
should after the trial be given according to the merits, ignoring defects in the pleadings. ${ }^{4}$

Lest these rules, as thus stated in the abstract, be misleading or seem too matter-of-course, a concrete case may well be given that will illustrate these rules and at the same time distinguish them from rules developed in common law pleading and in equity pleading.

Suppose, in an action for the breach of a contract or in an equity suit for specific performance, the defendant promisor wishes to rely on a right to rescind because of a misrepresentation of fact made by the plaintiff which induced him to enter into the contract. It might be that he can prove that the representation of fact was made by the plaintiff, that it was false, and that it induced him to enter into the contract; but there is conflicting evidence as to whether or not the plaintiff had known that the representation was false. The substantive law might also be in doubt, the defendant insisting that the misrepresentation, even though innocent, is a good defense, but the plaintiff insisting that scienter must be proved. Under these circumstances, the defendant would file a plea setting up the misrepresentation but omitting any allegation of scienter. The plaintiff would move to strike (at common law, he would demur; in equity, he would set the plea down for an argument), and at the argument he would insist that innocent misrepresentation is not a good defense. The ruling on that motion would depend upon the trial court's determination of the substantive law problem.

Suppose the court overruled the motion, holding the plea good. What would be the effect of that ruling, assuming that the plaintiff put the plea in issue? There are three quite different possible answers to that question.

I. The ruling might be held to bind the parties throughout the contest,

1I This idea is at the basis of all recent pleading reform. The method here suggested for carrying out that idea seems as fair as, and much more direct and certain of success than, other methods for which this suggestion is a substitute. Present rules waiving defects of substance are quite limited in scope or are too general to impress the courts. See Ill. C.P.A. $\S 42$, Smith-Hurd, Ill. Rev. Stat. I935, c. I10, § 166; Cahill's New York C.P.A. \& 278 (6th ed. I93I) (compare \& 279); infra note I02. The methods usually relied on to reach the desired result are: (I) The courts are asked to construe the pleadings liberally. III. C.P.A. $\$ \S 33$ (2) and 42 (2), Smith-Hurd's Ill. Rev. Stat. 1935, c. II0, $\delta$ 157 (2) and I66 (2); Cahill's New York C.P.A. $\$ 275$ (6th ed. I93I). (2) Very liberal rules for amendments are prescribed. III. C.P.A. $\$ \$ 46,92(a)$, Smith-Hurd's IIl. Rev. Stat. 1935, c. x10, $\$ \S$ 170, 216(a); Cahill's New York C.P.A., rule I66 (6th ed. r93I); Rules of Civil Procedure, art. I8, Am. Jud. Soc. Bull. XIV, 74 ff. (IgIg); Scott, Fundamentals of Procedure in Actions at Law, c. V (rg22). When an objection is raised because of a defect in the pleading, there is little difference in substance between the order sustaining the objection when there is an absolute right to amend, and the order overruling the objection. Compare: Clark and Moore, A New Federal Civil Procedure: II-Pleadings and Parties, 44 Yale L. J. I29I, I299 ff. (I935). 
in the trial and in the appellate courts. This is the equity rule regarding the sufficiency of pleas, but not of bills or answers. This result might be "explained" by either of two theories. One would rely on' res adjudicata or "the law of the case." ${ }_{42}$ The other, given in the equity cases, would suggest that it would be unfair for the plaintiff first "to put the defendant to his proof" (i.e., require him to prove the allegations) and then deny that those allegations amount to a sufficient defense. ${ }^{43}$ Under this position, the defendant wins though the substantive rights may be with the plaintiff. The appellate court may state the substantive law as requiring the proof of scienter. Scienter was not proved. A judgment for the plaintiff would follow if the case is decided on its merits. Yet the defendant wins because of the pleading rule that forecloses a consideration of the legal sufficiency of the plea and requires the defendant to prove only his plea, whether legally sufficient or not. This sacrifice of substantive law rights on the altar of a rule of pleading should shock a bar interested in real justice. ${ }^{44} \mathrm{In}$ mitigation, it should be said that there has been little tendency to extend the rule to other pleadings than the seldom used equity plea, ${ }^{45}$ and its unjust application to these pleas is restricted by certain practices in ruling on objections to the pleas..$^{6}$

${ }^{2}$ This doctrine is applied when the ruling is given or affirmed by an appellate court; as a general proposition, the parties are then bound by the ruling, and can not question it on a new trial or on a second appeal, even though the second appeal may go to a higher court than the one making the ruling. See 22 Harv. L. Rev. 438 (Ig09); 4 C.J. rog3 ff. (rgr6).

43 Harris v. Ingledew, 3 P.Wms. 9I ( 1730 ). This rule can be found in all the texts on equity pleading and in many cases; in nearly all of these cases, the rule is merely dictum or a makeweight added after the court has expressed an opinion that the plea was legally sufficient. Story, Equity Pleading $\S 697$ (6th ed. I857); Hughes v. Blake, 6 Wheat. (U.S.) 453 (r821), Hinton, Cases on Equity Pleading 38 I (I927). Compare Ewald v. Ortynsky, 78 N.J. Eq. 527, 79 Atl. 270 (I9II), Hinton, Cases on Equity Pleading 387 (1927). Perhaps the true reason for the rule was stated in the argument of counsel in Harris v. Ingledew: "Otherwise the defendant might be tricked by the plaintiff, who having found, that the defendant had made a slip in his plea, might decline arguing it, and reply to it." This failure of the plaintiff to give notice of the defect should not be so severely punished, but neither should it be rewarded as it is under the common law rule. For a compromise, see article 2, section 3, of proposed rules, infra.

44 When on a first appeal the plea is held good by an appellate court, there is a stronger argument in favor of the rule which binds the parties to this "law of the case." See note 42 supre.

45 But see McCarty, Attacking a Defective Pleading, 2o Iowa I. Rev. 49, 50, 55, 65 (I934). Many of the cited cases are little if any better than dicta for the view expressed in the article to the effect that this rule is generally recognized in Iowa.

${ }^{46}$ In practice, this rule did not work injustice in many cases in equity, as it was limited to the plea, and the defendant was not seriously prejudiced if he was required to answer, setting up the same defense. The chancellor ordinarily would not sustain a plea if its validity was really doubtful; the problem would be saved for later consideration (and appeal) by an order to "let the plea stand for an answer," or "let the benefit of the plea be saved to the hearing." Story, Equity Pleading $\$ \S 698$ and 699. (6th ed. 1857). 
II. Taking the opposite extreme position, the plaintiff might be permitted to raise the objection anew both at the trial, where he is entitled to an instruction requiring the proof of scienter, and after the trial on a motion for judgment non obstante veredicto. This is the common law rule, ${ }^{47}$ tempered by the permitted use of more than one plea..$^{8}$ To the extent that this rule allows a reconsideration of the substantive law at the trial, and a victory for the defendant only if he proves a good defense, this rule is sound; the courts almost everywhere are rejecting the equity rule which allowed the defendant to win by proof of the insufficient plea. But if the defendant actually proves a good substantive law defense, judgment should be given for him in accordance with the merits of the case, and not for the plaintiff on the pleadings. After a fair trial, the judgment should follow the decision on the merits, whether for the plaintiff or for the defendant. The equity rule is unsound when it gives a decree for the defendant on proof of an unmeritorious plea; the common law rule is equally objectionable when the judgment is given for the plaintiff notwithstanding a fair trial and verdict on the merits for the defendant. The common law rule is to this extent unsound in theory, even though in practice this rule is tempered to such an extent that the severe penalty of judgment non obstante veredicto is only occasionally imposed. ${ }^{49}$

III. A compromise between those two positions is here proposed for the new Federal rules. Though the plea is insufficient, the defendant must prove a good defense. If he proves a good defense, he is entitled to judgment regardless of the legal insufficiency of the plea. This view renounces both the equity rule permitting the defendant to win by proving the insufficient plea and the common law rule giving judgment against the defendant because of his error in pleading in spite of his proof of a good defense. In both cases, the proposed rule neither benefits the defendant nor bars him because of his error in pleading an insufficient plea; in place of the judgment controlled by the pleadings, the proposed rule substitutes a judgment based on the merits of the case as proved at the trial.

${ }^{47}$ Shipman, Common Law Pleadings 533 (Ballantine's ed. 1923); Martin, Civil Procedure $\S 37 \times$ (I899).

${ }^{8}$ In this case, the defendant would file two pleas, one alleging innocent misrepresentation and the other fraudulent misrepresentation. Though the first plea might be held bad after verdict, the defendant would be given judgment if the jury found the second plea proved. The plaintiff was given judgment non obstante veredicto only if the defendant confessed the declaration and failed to set up a good avoidance.

49 For the use of two pleas, see note 48 supra. The rule is further tempered by the rule that, after verdict, the pleading should be construed most strongly in favor of the pleading, ignoring all errors in form. Shipman, Common Law Pleading 53I (Ballantine's ed., I923). 


\section{Objections during the Trial Stage}

The discussion of the effect of the ruling on the motion necessarily disclosed the attitude toward objections to the pleadings made during the trial stage and upon appeal. The error is one that "appears on the face" of the pleading. The party who filed the erroneous pleading, and the opponent who has not objected by motion, have both contributed to the failure of the pleadings to carry out the rules and to prepare the case properly for trial. Since both parties are at fault, it is unfair to penalize either party by benefiting the other.

The common law rule often benefits the party who failed to object to the faulty pleading. The shrewd (and ethical) lawyer ${ }^{50}$ for the defendant who discovers an error in the common law declaration no longer hastily attacks by demurrer. The prize coup is the motion in arrest of judgment used after having the benefit of a chance to win before the jury. ${ }^{5 x}$ If it is feared the error is not serious enough for the court to sustain a motion after an adverse verdict, the almost equally effective strategy is to wait until the jury is selected and then to object to the introduction of any evidence because of the lack of a good cause of action stated in the declaration. ${ }^{52}$ The terms imposed for the privilege of amending are usually severe enough to discourage the plaintiff effectively.

While such methods furnish some of the happiest moments for the skilled lawyer, they lead neither to improved pleadings nor to increased popular respect for the law. The abolition of such methods should be accomplished by express edict. It is true that some rules have failed to reach this result though they were probably intended to accomplish it. The fault lay in the unnecessarily vague and meaningless wording of the rules. ${ }^{53}$ A rule can be drawn that will clearly ban attacks on the legal sufficiency of the pleadings after the trial stage has been reached.

It might be argued that these methods of attack during and after the

so Certainly it was not unethical for a lawyer to demonstrate his "art" in pleading. The common law courts carefully protected this art from attack by statute. "Now the moderation of this statute is such, that it doth not utterly reject form; for that were a dishonor to the law, and to make it, in effect, no art." Heard v. Baskerville, Hob. 232 (I6I4), Cook and Hinton, Cases on Common Law Pleading 247 (1923), quoted in Scott, Fundamentals of Procedure 145 (I922).

sx Stephens, Pleading 230, 23r, 246, 270 (Andrews' 2d ed. I9or). Shipman, Common Law Pleading 527 (Ballantine's ed. I923).

52 Scott, Fundamentals of Procedure I50, note 20 (I922). Compare Baker and Conrad v. Chicago Heights Const. Co., 282 Ill. App. 459 (1935). But see Story, Equity Pleading $\$ 464$ (6th ed. 1857 ).

53 Usually the reform is a vague, indirect attack by decreeing liberality in allowing amendments, instead of a clear, direct attack on the allowance of an objection. See note 4I supra. 
trial should be retained because they furnish about the only real sanction left in practice today for enforcing the pleading rules. If all penalties are removed, there will be no incentive for a party either to plead carefully himself or to object to errors in the pleadings of his opponent. But the answer to that argument has already been given. When a pleading is attacked during the pleading stage by motion, the reasonable penalty of costs is imposed, not merely in the flagrant case, but in practically every case. This swift and sure penalty should be more effective in enforcing good pleading than the slight chance of a successful objection during the trial stage..$^{54}$ In addition, the preposed rules encourage the raising of the objection during the pleading stage.

Every benefit claimed for pleading can best be obtained by thus raising the objections by motion during the pleading stage. Only in this way will the defects be removed in time for the pleadings to serve their purpose of preparing the case for trial. Complications, such as those caused by defects in parties, will be removed. The issues will be properly limited and determined. The burden of proof will probably be indicated. Proper notice of the claim or defense will be given. And perhaps most important of all, the disputes of substantive law will often be settled. If this substantive law issue can be argued on motion, when briefs can be submitted and due consideration can be given it, a sound decision is more apt to be reached than if the issue is raised by an objection to evidence or instructions when even the hurried and ill-prepared arguments will be impeded by the pressure of the trial. The motion, with its order settling the theory of the case and prescribing pleadings properly serving their functions, will insure a trial of the merits with a minimum of surprise and a maximum of orderly consideration of material evidence.

These indirect results are the important advantages favoring the rule abolishing objections to the pleadings made during the trial. In addition, there will be the slight advantage in the direct result that the trial may be made a little less complicated by the removal of some of the arguments regarding the pleadings. These arguments indicate a dislike for the English practice which encourages the postponement of the arguments or objections in law until the trial stage. However, the present proposals are not

st Higgins, Am. Jud. Soc. Bull. XI, 56 (I916): "Rules requiring the ultimate facts and against prolixity, scandal and the like are of no benefit unless enforced. . . . The enforcement [in England] of the rules of good pleading by penalization of costs has secured simplicity and prevented that carelessness which, in some jurisdictions of the United States has been the occasion of technical squabbles that occasion delay and burdened the courts with the necessity of making distinctions in order that the very right of the case might be reached for determination." Also see $i d$., at 102. 
inconsistent with that practice, or with the present Federal Equity Rules. So long as the defendant's objection in law must be raised during the pleading stage, it is not essential that it be made in a separate motion rather than in the answer.

Two types of objections that relate directly to the pleadings can still be made during the trial.

a) Objections to Evidence, Pleadings and Findings.-As heretofore explained, the right of each party to a judgment based on a fair trial on the merits should in no way be restricted; it should in fact be strengthened by an elimination of those rules which now result in judgments based on considerations other than the merits. The instructions given and refused, and the rulings on the objections to evidence, will still show the legal theory on which the case was tried. While a "theory of the case" may have been developed during the pleadings, and this theory should ordinarily be followed consistently at the trial, objections to evidence and instructions should still be made for the purpose of saving rejected theories for review. The losing party should, as heretofore, be entitled to a new trial if the rulings on objections during the trial show that an erroneous legal theory was applied to his prejudice. Existing safeguards necessary to insure a fair trial on the merits are thus retained.

In connection with these objections, motions for instructed verdicts should receive careful attention in the rules. Unless the constitutional objection appears insurmountable,,$^{55}$ encouragement should be given the

$5 s$ In Slocum v. N.Y. Life Ins. Co., 228 U.S. 364,33 Sup. Ct. 523, 57 L.Ed. 879 (I9r3), the trial court denied the defendant's motion for a directed verdict at the close of the evidence. After verdict for the plaintiff, the defendant raised the objection again by motion for judgment on the evidence notwithstanding the verdict. The trial court denied this motion also, but the Circuit Court of Appeals reversed the case with direction to sustain the second motion and give judgment for the defendant. This was all in accordance with the state practice, which was typical of the most modern acts. But the Supreme Court, in a five to four decision, held this to be a violation of the right to trial by jury guaranteed for the federal courts by the Seventh Amendment, and ruled that a new trial must be granted the plaintiff. In view of the division of the court on that case, and the weight of the state authorities contra, a reconsideration by the Supreme Court would be desirable. While the practice of renewing the objection by motion for judgment notwithstanding the verdict is in accordance with the usual practiceIll. C.P.A. § 68(3) and Rule 22, Smith-Hurd's Ill. Rev. Stat. I935, c. IIO, § I92(3); Malewski v. Mackiewich, 282 Ill. App. 593 (1935) - the name of the second motion and the nature of the procedure may have unduly influenced the majority of the court. But in view of this decision, the second motion might well be abandoned. However, the court will permit the trial court, in accordance with the most modern state practice, to postpone the ruling on the motion for a directed verdict, and allow the trial or appellate court to render final judgment on the postponed motion. The verdict in accordance with a peremptory instruction seems to be a mere formality, especially when the instruction will be required on the second trial (with the same evidence) by the doctrine of the "rule of the case." Such a formal verdict might be held unnecessary for a judgment on the first motion. The appeal should be taken to the ruling on the motion for a directed verdict, without a motion for judgment on the evidence notwithstanding 
practice of postponing the ruling on this motion until after the verdict, as a finding of the jury for the moving party will eliminate many arguments and chances for a reversal. If this postponement is permitted, the rules should also give the appellate court the power, on reversal, to give the proper order without remanding for a new trial. At the same time, when a ruling is made on a motion for a directed verdict, either by the trial or an appellate court, the losing party should have the same opportunity to move for a new trial as he would have had if this ruling had been made before the verdict. ${ }^{56}$

b) Variance.-The objection to evidence or instructions based on a variance between pleading and proof is usually not a substantial objection. As a rule, each party is well aware of the nature of the opponent's claim or defense. If one party fails to state his real position, the other lays plans to defeat the position taken in the pleading and to pretend surprise and protest vociferously against the admission of evidence of the true position. Generally the objection is a "technical" one and should not be successful. However, at common law the objection often led to the exclusion of matter not accurately described in the pleading. ${ }^{57}$ How should the common law rule be attacked?

the verdict. This procedure has the advantage of greater simplicity in addition to the increased chance of being held constitutional.

${ }^{56}$ When a plea fails to allege sufficient facts for a good defense, the plaintiff will often refrain from objecting by motion (demurrer), and then move for a directed verdict if the defendant fails to prove the omitted fact. This should be discouraged, as our object should be to have pleadings give notice of the facts that must be proved. Also this "trick" (Harris v. Ingledew, note 43 supra) should not lead to a final judgment when the defendant really has evidence which he would have introduced if he had known the omitted fact was in issue. The rules should expressly encourage the granting of a new trial in such a case; this is in addition to a rule saving to the losing party his opportunity to move for a new trial. See last sentence of art. 2, $\$ 3$ of proposed rules, infra. Compare Cahill's New York C.P.A., rule I66(2) (6th ed. I93I): "A complaint or counterclaim need not be dismissed on the trial because of failure of or defect in proof, if it shall be made to appear that the evidence to supply the defect can be produced. In such case the judge may thereupon receive such evidence or adjourn the trial, or direct a new trial, on such terms as in his discretion shall be proper." That rule is subject to three serious objections: (x) The word "may" fails to suggest any criterion for determining when the permission should and when it should not be granted; yet final judgment often depends upon the exercise of this discretion. (2) Not being limited to cases where the failure of proof is justified by the state of the pleadings, the rule does not bar insubstantial requests (the limitation here proposed should be substituted for "may"). (3) The same liberality should be prescribed for variances in answers and other pleadings.

57 Perhaps the most unreasonably strict cases on variance at common law were in special assumpsit where an error in "identifying" the contract by a slight misstatement of the consideration or the promise was often treated as fatal. For illustrations, see the following cases reprinted in Cook and Hinton, Cases on Common Law Pleading 360-369 (I923): Blythe v. Bampton, II J. B. Moore 387 (1826); Penny v. Porter, 2 East 2 (I80r); Simms v. Westcott, Cro. Eliz. 147 (I590); Curley v. Dean, 4 Conn. 259 (1822). 
One suggestion has been to adopt "notice pleading." ${ }^{8}$ This merely implies that the pleading is satisfactory if it gives reasonable notice. Aside from the facts that notice is seldom needed by the adverse party and that pleadings serve other and more useful purposes, this change of emphasis really does not avoid the difficulty. There can still be a "fatal variance" between the position taken in the notice pleading and the position taken in the evidence. ${ }^{59}$ In fact, an emphasis on the notice-giving purpose of pleadings may lead to an emphasis on the importance of giving correct notice. The effective remedy would seem to lie in the opposite direction: an emphasis on the unimportance of notice. This leads to the position that the pleading guilty of a variance from the true facts is objectionable only in that it failed to produce the benefits expected of pleadings, particularly the framing of the true issues; the punishment for such a defect should be appropriate for the offense, and should ordinarily consist only of the assessment of the costs of litigating the unpleaded issues..$^{60}$

Another suggestion for limiting the variance objection has been to define it almost out of existence. The New York Civil Practice Act provides: "A variance between an allegation in a pleading and the proof is not material, unless it has actually misled the adverse party, to his prejudice, in maintaining his action or defense on the merits." "This rule is quite indefinite, the two words, "misled" and "prejudice," both leaving the court much discretion in drawing the line between "material" and "immaterial" variances. The result has been that this line is not far from the line drawn at common law or in equity between the "fatal" and the "immaterial" variances. ${ }^{62}$ The rule has failed in its purpose. ${ }^{63}$

${ }^{8}$ Supra note 8.

59 "The notice required of the details of the pleader's cause becomes, after all, a question of legal notice, governed by precedents and rulings, rather than actual knowledge of the defendant; the latter is too shifting and variable a ground to be practicable." Clark, Code Pleading 30 , note 96 ( 1928 ).

${ }^{60}$ A clear distinction should be made betwen "notice pleading" as a plan for a system of pleading and "notice pleading" as a rallying cry for a group of pleading reformers. The reformers are primarily interested, not in a new system, but in rules which will lessen the importance of pleading and will cease to retain doctrines which have had the unfortunate effect of emphasizing and retaining outworn distinctions and rigid rules in our law. I should like to be classed in this group. But as a system of pleading, "notice pleading" has not been carefully developed in many of its details. The sanctions for enforcing its rules, in particular, have received little attention. The suggestions in this article are not all inconsistent with "notice pleading" rules, but are in fact advanced with the hope that they will prove to be of value as contributions to the reform plans of the "notice pleaders."

62 Cahill's New York C.P.A. \$ 434 (6th ed. r93r).

${ }_{62}$ See cases in annotations to $\$ 434$.

${ }_{63}$ Though this method of limiting variances does not seem to be the best method of attack- 
This New York provision is but another illustration of a previously noted tendency in pleading reform. A final decision based on the violation of a rule of pleading rather than on the merits of the case is under attack. The common practice is to blame, and to attempt to restrict, the rule of pleading, instead of the penalty. Again this method is open to the two objections: a variance might well be discouraged by a reasonable punishment even though it should not be labelled "fatal" or "material" for the purpose of the imposition of the serious common law ${ }^{64}$ penalty; and even the "material" variance should not be punished by the severe penalty of final judgment.

While the problem of variance will necessarily remain to worry the bench and the bar, a direct attack on the penalty of judgment will substantially limit its importance, and with the advantages to the objector so greatly reduced, the number of objections based on variance will be materially decreased. ${ }^{65}$ It should never be necessary to render a final res adjudicata judgment because of a variance. When the variance is "material," an amendment should be allowed; even that formality can be waived if it is "immaterial." Of greater importance, terms should always be imposed for the privilege of relying on the unpleaded matter. In most cases there is little real surprise or prejudice, and reasonable costs will suffice. In a few cases, a continuance will be necessary to allow the objector to investigate the new cause of action or defense. When the trial is by the court, the added costs will be slight, but the entire costs of litigating, and perhaps the expenses of investigating, the new matters might be assessed. When the trial is by jury, actual surprise and the need of considerable time for investigating should call for the dismissal of the jury with the added

ing the problem, the New York rule might be improved by making it more definite. This seems to be part of the plan suggested in McCaskill, One Form of Civil Action, But What Procedure, for the Federal Courts, 30 III. L. Rev. 4I5, 440 (1935). The New York rule is copied as part of art. $2, \S 4$ infra, but the distinction between a "material" and an "immaterial" variance is not made important.

${ }^{64}$ In equity, the variance rules should not now be as strict as at common law. Without a jury trial, a continuance for an opportunity to prepare a defense to the new matter can be granted without prejudice to the objector. But some of the equity cases applied the variance rules in much the same spirit as at common law. The following cases are reprinted in Hinton, Cases on Equity Pleading I60-I70 (I927): Gurney v. Ford, 2 Allen (Mass.) 576 (I86I); Smith v. Smith, 4 Johns. Ch. (N.Y.) 28I (I820); Dorn v. Geuder, I7 I Ill. 362, 49 N.E. 492 (I898).

${ }_{65}$ Two present limitations on the raising of objections based on variance will be retained without special mention: ( $x$ ) An objection to evidence because of a variance must be sufficiently specific to identify the error, so an amendment may be made to avoid the variance. 3 C.J. 802, note 95 (Igr5). (2) An objection based on a variance will not be considered when raised for the first time on appeal. 3 C.J. 796, $\$ 720$ (I9I5). The proposed rules (art. 2, § 3, infra) require the objection to be made during the trial. 
expense of a complete new trial. This should not be ordered except when actual prejudice would result if only a short continuance were granted. When the new trial is really necessary, the terms might be very severe, and in case a variance by the defendant will delay a judgment in favor of a plaintiff who has made out a convincing case, the defendant might be required to give bond for the costs or even for the payment of the judgment. In prescribing terms, the court must be given much discretion, but the rules should be as definite as possible in stating the policy to be followed, banning the res adjudicata judgment, and indicating the possibility in most cases of continuing without serious prejudice or delay. ${ }^{66}$

Separate treatment will have to be given the case where the variance constitutes a shift from a legal claim or defense to an equitable one, or vice versa. The common law barriers to a shift from one writ to another have been broken down rather easily. However, one distinction between law and equity can not be so easily abolished. The right to a trial by jury at common law is preserved by constitutional provisions. Nevertheless, the right to make this shift should be made absolute, and the procedure should be simple. Even when made during the course of the trial, the shift from legal to equitable should not differ from the shift in any other variance. With or without a continuance, the trial can continue before the court, the jury (if there is one) being dismissed. When the shift is from equitable to legal, the party guilty of the variance may be barred from claiming a right to a jury trial as one of the terms for permitting the amendment. But if the other party insists upon his right to a jury trial, a continuance, with a new trial, will be necessary. In imposing terms for the privilege of making this type of amendment, the objecting party should be adequately protected. The right to a trial by jury is still considered so hallowed that indirect pressure should not be applied to induce him to waive the jury even though the trial by court is now so greatly favored. This part of the problem of variance will necessarily be covered by the separate rules on the transfer of cases between law and equity. ${ }^{67}$

${ }^{66}$ Many states have rules that appear to be extremely liberal in allowing amendments, but are too broad and general to point out the desirable order to the trial court. Ill. C.P.A. $\$ 46(3)$, Smith-Hurd's Ill. Rev. Stat. I935, c. Iro, § I7o(3) provides: “A pleading may be amended at any time, before or after judgment, to conform the pleadings to the proofs, upon such terms as to costs and continuances as may be just." See the discussion of this provision, McCaskill, Illinois Civil Practice Act Annotated Ir3 (1933). Compare Rules of Civil Procedure, art. r8, Am. Jud. Soc. Bull. XIV, 74-78 (rgrg), especially § 9: "At any time after trial, whether before or after judgment, the trial or appellate court may allow any amendment necessary to make any pleading conform to the proof, so far as may be just." This rule takes much of the ambiguity out of the word "may," and at the same time takes much of the apparent liberality out of the rule.

${ }^{67}$ See III. C.P.A., § 44(2), Smith-Hurd's Ill. Rev. Stat. I935, c. 110, § 168(2); McCaskill, 


\section{Objections after Trial and on Appeal.}

The previously defined policies would require that, after a fair trial on the merits, the judgment should be in accordance with those merits, and errors in pleading should never be the basis for motions in arrest of judgment or for judgment non obstante veredicto. Even motions for a new trial based on such errors should be banned, unless a case can be suggested where the defect in the pleadings might cause substantial injustice of a type that would not give rise to an appealable objection during the trial..$^{68}$

The corollary to this has already been stated. Since the judgment is to be given, not on the pleadings but on the merits, the right to a fair trial must be safeguarded by ample appellate review if erroneous rulings during the trial result in substantial injustice to any party. The suggestions here made do not require a detailed discussion of motions for new trials or of appellate review.

\section{PROPOSED RULES}

These suggestions for abolishing the penalty of judgment on the pleadings should be stated in the form of proposed rules. This can be done only in a tentative sort of way, as the suggestions do not cover an integral part of the rules separate from the rest. It is true that these proposals are consistent with any "type" of pleading that might be adopted. ${ }^{69}$ Nevertheless, the general plan, vocabulary, and even the substance of the suggested rules will depend largely upon the whole set of rules of which these will constitute only a small part. This is particularly true because the motion is here used for raising objections, and motions are used so extensively for other purposes during the pleading and the trial. ${ }^{\circ 0}$ As the committee now drafting the pleading rules has not made the first draft available, consistency with those rules is impossible. For that reason, these proposals will be of value only to the extent that they may contain ideas of substance that can be properly incorporated or adopted in the new rules.

With this explanation that defects of form should be ignored, the following rules are suggested for the purpose of carrying out the major part of the above proposals. Perhaps it is desirable to repeat that all other rules, covering pleading, trial practice, or appellate court practice, should be

One Form of Civil Action, But What Procedure, for the Federal Courts, 30 III. L. Rev. 4I 5 , 439 (I935).

${ }^{68}$ See note 38 supra and note 74 infra.

${ }^{69}$ These proposals involve the enforcement of the other pleading rules, rather than the substance of these rules. They are not inconsistent with "notice pleading" or any compromise between that and "issue pleading," but should supplement any such system.

$7^{\circ}$ Recent experience has indicated that confusion is not seriously increased by this wide use of the name "motion." See note 27 supra. 
examined carefully for the purpose of eliminating final judgment as a penalty for a breach of the rules. ${ }^{7 x}$

\section{Article i-Pre-Triat Objections to Sufficiency of Pleadings}

SECTION I. Motions for Defects in Form or Substance.-All objections to the legal sufficiency, substance or form of pleadings, such as were formerly made by dermurrer, motion or exception, shall be made by motion. Each motion shall state in reasonable detail the ground or grounds for the objection, and may state the relief or kinds of relief, in the cumulative or alternative, to which the moving party may deem himself entitled.

[SEC. 2. Construction of Rules Relied on.-In determining the validity of an objection made by such a motion, the rules of pleading shall be interpreted and applied in such a way that the pleadings will best serve their purpose of preparing the case effectively for trial. $]^{7^{2}}$

SEC. 3. Cosis.-To the end that motions resulting in the improvement of defective pleadings shall be encouraged and motions lacking merit shall be discouraged, the losing party on the motion shall ordinarily be taxed reasonable costs to be paid to the winning party. These costs shall, except in unusual cases, be a fixed sum as set by rules for each circuit or district, and shall not, prior to January I, I940, exceed ten dollars for any circuit. These costs shall be summarily taxed and shall not abide the event of the action unless otherwise provided by the court. No costs shall be assessed hereunder if the defect objected to is removed or the relief requested is adequately supplied, by an amendment, bill of particulars or otherwise, within five days of receiving notice of the filing of the motion, or within such further time as the parties may agree to or the court may allow.

Sec. 4. Order.-The order rendered with the ruling on the motion shall not be limited to the relief demanded in the motion, but shall be appropriate to the objection made in the motion and found valid, such as: that all or part of the defective pleading be stricken, that an allegation be stated in more detail or the pleading be made more definite and certain, that a cause of action or party improperly joined be dropped, that necessary parties be added, that amendments be made removing designated defects, or (if the motion is overruled) that the party answer over. A final judgment on the pleadings shall not be given unless it appears that the defect can not be cured by

${ }^{7 x}$ Compare Costigan, The Spirit of Code Pleading, Ir Ill. L. Rev. 5I7, 539 (I9I7): "The subject of this paper is the spirit of code pleading. It is, after all, a very narrow scope. For the problems of pleading are really not our most troublesome problems in reforming procedure. .... The delays and the expense are experienced after the pleading stage is passed and the real trouble, then, is not with code pleading, but with the code procedure that does not relate to pleading proper." Many a desirable rule of trial or appellate court practice is made obnoxious by the penalty of judgment or dismissal by which it is enforced.

${ }^{2}$ Bracketed to indicate that this may be omitted. It seems well to emphasize repeatedly in the rules that pleadings are merely a means to an end. There should be a separate section in the rules to this effect. Compare Cahill's New York C.P.A. § 275: "Pleadings must be liberally construed with a view to substantial justice between the parties." Does this New York section mean that a just judgment should be given on the pleadings, or that the pleading rules should be loosely enforced and in doubtful cases the pleading should be held to comply with the rules, to the end that the judgment should be determined by the merits and not by the pleadings? 
amendment, or the losing party expresses a determination to stand by his position for the purpose of appeal, or he fails to carry out the order within the time therein prescribed or such further time as may be allowed. If the judgment given in accordance with one of these exceptions is reversed on appeal, judgment shall not be given against the appellee but the case shall be remanded for the entering of the appropriate order.

SEC. 5. Immediate Appeal.-An immediate appeal can not be taken from the ruling on the motion except: ( 1 ) When a final judgment is given in the order; (2) When the losing party permits final judgment to go against him by indicating his desire to stand by his position or by failing to carry out the order; (3) When otherwise provided by statute or rule; or (4) When leave for an immediate appeal is granted by the court entering the order.

SEc. 6. Ruling Shall Not Prejudice Later Objection.-When the motion raises a question as to the substantive law applicable to the case, the theory developed for the ruling on the motion shall ordinarily be followed consistently throughout the trial unless it shall appear to be definitely erroneous. However, the ruling on the motion shall not affect the substantive rights of the parties. The rejected theories of law may later be advanced for the purpose of getting rulings concerning evidence, instructions or findings which may be the basis for a motion for a new trial and an appeal.73

SEC. 7. Error in Ruling-New Trial-Appeal.-An error in the ruling on the motion shall not be the basis for granting a new trial, or a reversal on appeal.74

SEc. 8. Defects Waived by Going to Trial.-All defects in the pleadings, whether of form or of substance, are waived by going to trial on the merits, and no objection shall thereafter be made that is based upon the legal insufficiency of a pleading; provided however, that such waiver by a party to a legally insufficient pleading shall not estop him from raising objections to the proof, as being insufficient, whether an objection has been made to the pleading or not.

\section{ARTicle 2-ObJections at TrIat}

SECTION I. No Objections in Law.-After a cause has been reached on the trial calendar or referred to a master for a hearing, no objection shall be made that is based on an error in the pleadings that might have been attacked by a motion during the pleading stage.

SEc. 2. Objections to Evidence, Instructions and Findings. - Each party is entitled to a fair trial on the merits of the case, regardless of errors in any pleading, and for the

${ }^{73}$ As thus worded, this rule does not cover the effect of a ruling by an appellate court. Whether or not the usual theory of the "law of the case" should be changed, is a matter that should be stated in the rules on appellate court practice, if such rules are within the field in which the act gives the court rulemaking powers. For the present tendency, see 42 C.J. $55^{8}$ (1927).

74 See note 38 supra and text at note 68 . It seems unnecessary to add any limitation to this proposed rule, unless someone suggests a case where this rule would work an injustice. If such a case is suggested, the following limitation might be added to the rule: "Unless the ruling necessarily has affected the substantive rights of the party and no other opportunity has been afforded him to assert the rights by insisting on a fair trial on the merits." Compare Cahill's New York C.P.A. § Io6 (6th ed. r93r), which covers all rulings of the trial court. This is also true of the suggestion in Pound, Some Principles of Procedural Reform, 4 Ill. L. Rev. 49r, 505 (rgro). 
purpose of preserving this right, he may make objections to evidence, or to instructions given or refused, or to findings, which are erroneous and are prejudicial to him.

SEc. 3. Motions for a Directed Verdict. - The court may reserve decision on a motion for a directed verdict until after the verdict of the jury has been received. If the verdict is against the moving party and the motion is then granted, the verdict of the jury shall be recorded as rendered but the judgment shall be given on the motion without the necessity of a verdict in support.75 The losing party on this motion may, after the ruling thereon, move the court for a new trial, and if this motion is overruled, he may appeal the two rulings, asking for a reversal on alternative grounds. If the ruling on the motion for a directed verdict is reversed on appeal, judgment shall be entered on the motion or on the verdict in accordance with the new ruling; provided however, that the appellee shall have the same right to move for a new trial as though the lower court had originally ruled properly on the motion for a directed verdict, and provided also, that the appellate court may direct that such motion for a new trial be filed by the appellee directly with such appellate court for its consideration. If the motion for a directed verdict is granted because of the failure of the opponent to prove a fact erroneously omitted from the pleading of such opponent, such opponent shall be entitled to a new trial upon a showing by affidavit: (a) that favorable evidence is available to entitle him to submit to the jury the issue based on such omitted fact, and (b) that such evidence was not presented at the trial because of the failure of the moving party to indicate the existence of that issue by objecting to the legal sufficiency of the defective pleading by a motion during the pleading stage of the case..$^{6}$

SEC. 4. Variance.-A variance between the pleadings and the proof is not material, unless it has actually misled the party objecting to the variance, to his prejudice, in maintaining his action or defense upon the merits. When the variance is not material, the court may order an immediate amendment or may admit the proof of the new claim or defense without an amendment; the court may also tax as costs against the party guilty of the variance any or all of the expenses of litigating the new issues, which costs shall not abide the event. To the end that each party shall have an opportunity to enforce his substantive rights, an amendment shall be permitted, on such terms as the court may impose, with or without a continuance and with or without commencing the trial anew, even when the variance is material, if the party would otherwise be barred from setting up his rights by the doctrine of res adjudicata, the statute of limitations, or otherwise. In all cases where the objector should be able to proceed with the trial because he should have had reason to suspect the possibility of the advancement of the new claim or defense, and in all cases where an adequate continuance is practical (considering the method of trial, simplicity of the evidence on the new issues, and the availability of witnesses), an amendment with a continuance, without commencing the trial anew, shall be ordered, on such terms as to costs, and bonds for

75 This should make unnecessary a separate motion for judgment on the evidence notwithstanding the verdict. See note 55 supra.

${ }^{76}$ See notes 43 and 56 supra. In Scott, Fundamentals of Procedure in Actions at Law I59I6I (I922), this problem is discussed and the suggestion is made that the new trial should be limited to the new issue. Accord: Pound, Some Principles of Procedural Reform, 4 Tll. L. Rev. 49r, 504 (rgIo). While the party here asking for a new trial won on the other issues, he is at fault and it is not unfair to submit all issues to the second jury. The arguments of policy on this question seem nearly evenly balanced. 
costs or payment of judgment, as the court may direct. The orders given when ruling on an objection based on variance shall not be the basis for a motion for a new trial unless the moving party clearly establishes that the ruling on the objection during the trial was so unreasonable, because of resulting prejudice, that it was an improper exercise of discretion. 77

\section{ARTICLE 3-OBJections AFTER TRIAL}

Section r. No Objections in Law.-No motion in arrest of judgment nor motion for judgment non obstante veredicto nor motion for a new trial shall be granted because of defects apparent in the pleadings.

SEc. 2. Variance.-No motion for a new trial shall be granted because of variance between the pleadings and the proof unless timely objection had been made thereto during the trial; and even when objection had been made, the motion for a new trial shall not be granted unless the moving party clearly establishes that the ruling on the objection during the trial was so unreasonable, because of resulting prejudice, that it was an improper exercise of discretion.

SEc. 3. Motion for a Now Trial.-Rulings on the objections to evidence, instructions or findings made during the trial may furnish the basis for a motion for a new trial if erroneous rulings resulted in substantial prejudice to the substantive rights of the party..$^{8}$

\section{II}

\section{DEFINITE AND INDEFINITE TERMS IN PLEADING RULES}

There is a prevalent belief that the techniques of equity pleading were superior to the pleading techniques developed at common law, and that the main object of the code was to extend the superior equity rules to cover both equity and law cases. That was certainly not true of code reform in this country. ${ }^{79}$ The equity bill and answer were interested in discovery, and prepared the case for its own type of trial.80 The law cases still constituted the bulk of the litigation, and the common-law emphasis on the raising of issues had led to rules better suited for preparing these cases for the jury trial. For this important purpose of raising issues, the common-law methods were therefore adopted by the codes; the corresponding equity rules were discarded..$^{8 \mathbf{r}}$

${ }^{77}$ The problem of transfer from law to equity, and vice versa, is left for consideration by a separate rule (note 67 supra).

${ }^{8}$ The rules regarding appellate review are not within the scope of these suggestions.

79 For a comparison with the English reform under the Judicature Act, see Pound, Some Principles of Procedural Reform, 4 IIl. L. Rev. 388,404 (xgro).

${ }^{80} \mathrm{It}$ is hardly necessary to call attention to the fact that both common-law pleading and equity pleading were products of long periods of development, and they varied greatly from century to century. The method of trial likewise varied greatly in equity, with the secret trial persisting in the federal courts until a recent date. Clark, Code Pleading Io, I3 (I928).

${ }^{8 \mathrm{I}} \mathrm{It}$ is sufficient to mention a few characteristics of equity pleading that were abandoned in favor of the opposite common-law rule: (a) pleading and discovery, or the basis for discovery, were combined and often confused in the one pleading instrument; (b) the bill antici- 
There was, however, an attitude in equity which was sought for the code: by comparison with the common law, pleading rules seemed to be much less important in equity; it was assumed that each case would be decided on its merits, with no technical rule of pleading preventing the ascertainment of the merits. ${ }^{82}$ This was to be the "Spirit of the Code."

The proponents of code pleading admit that this "Spirit of the Code" received rough treatment at the hands of the courts. They state this not as an admission but as an accusation. The blame is placed not on the code but on the unfriendly and unintelligent courts. To determine the fairness of this charge, the phantom "Spirit" must be captured and examined.

Where can the "Spirit" be found? Since the courts failed in their duty, we can not find it in the decisions under the codes. We must go to the equity cases.

It is submitted that the "Spirit" is to be found in two attitudes: ( $x$ ) the rules of pleading were not to be vindicated by the severe sanction of final judgment; and (2) the rules were much more flexible. The first of these two furnished the theme for Part I of this article. It is related to the second in this respect: flexible rules leave much to the discretion of the court; the severe penalty of judgment should not be imposed against the party who failed to guess in which way the court would exercise its discretion..$^{83}$ The penalty at common law naturally led to the development of

pated the affirmative defense and met it by an affirmative replication (if one) in the charging part of the bill; (c) pleadings were in issue when filed (i.e. a denial was not necessary, the answer "constructively denying" everything not admitted); (d) general denials were not needed and were not used; (e) the defendant had a choice of two methods of pleading his defense based on allegations of fact: answer or plea; $(f)$ different methods were developed for objections in law to form or substance: demurrer, motion, exception, plea set down for argument, hearing on bill and answer. Arguments of similarity based on Federal Equity Rules of IgI 2 are unsound as those rules are based more on the code than on traditional equity pleading; except for the sections on "parties," federal equity pleading can better be studied in a course on "Code Pleading" than in "Equity Pleading."

$8_{2}$ "Technical" decisions can be found in equity pleading, but they are the exception. Some are explainable by the fact that a court often carried its common-law attitude over into the equity cases, where the same court had jurisdiction of both. Some are the result of a reaction to the delay growing out of an easy attitude toward speed that developed with the easy attitude toward pleading rules. Most of them are cases where the pleading ground was merely a makeweight; the rule would be held to be merely discretionary if it led to a result not in agreement with the apparent merits. Thus the rule that the defendant is entitled to a decree if he proves his plea, though the plea is defective, can be found in hundreds of cases; but it would be diffcult to muster a half dozen where the plea was stated to be really defective, or even probably defective. And the rule has been held to be discretionary. Ewald v. Ortynsky, 78 N.J. Eq. 527, 79 Atl. 27 ( (I9II), Hinton, Cases on Equity Pleading 387 (I927).

${ }^{83}$ Freund, The Use of Indefinite Terms in Statutes, 30 Yale, L. J. 437, 442 (I921); note 5 supra. The common law penalty for bringing an action under the wrong writ became very 
definite rules. The same penalty under the code led to interpretations that, to the reformers, were disappointingly similar to the common law.

In spite of the partial retention of the common-law penalty of judgment, the rules might have been construed as flexible if they had been framed in language appropriate for flexible (indefinite) rules. But they were not. Judge Hinton was a severe critic of the draftsmanship of these rules, pointing out $(\mathrm{I})$ that indefinite rules were often prescribed where definite ones would have been more useful and (2) that even when flexibility was desirable, the language used by the rules had a misleading appearance of definiteness which proved to be the source of much litigation, most of it on a low plane.

While Judge Hinton was thus criticizing the language of the codes, his colleague, Ernst Freund, was completing the pioneer work in the field of legislation. One of the important contributions of this latter work concerned the use of indefinite terms in statutes. ${ }^{84}$ The work of these two great masters, differing though they did so materially in background and attitude toward law, may be combined: the teachings of Judge Hinton point out the defects in the codes, and the ideas of Mr. Freund suggest a way of avoiding them.

\section{A. DEFINITE AND INDEFINTTE TERMS COMPARED}

It is true that almost every word in our vocabulary has several different meanings or different shades of meaning. Rules expressed in such words are perhaps never perfectly definite. It is, however, also true that some rules are extremely indefinite while others are relatively very definite. Legal philosophy might well interest itself in the characteristics of the rules varying in degree of definiteness; the problem of determining the best degree for a particular rule is a problem encountered in every field of the law.

An example may be taken in the field of property. What uses may a riparian owner make of the stream that flows through his lands? In many semi-arid states of this country, the "prior appropriation" rule is applied. In other states the "reasonable use" rule has been adopted. How do those rules differ? The answers to that question illustrate the typical differences between definite and indefinite rules.

objectionable when applied to the borderline cases between trespass and case, where the proper remedy often depended upon whether the injury was the "direct" or only the "indirect" result of the plaintiff's act. There was naturally a demand for a statute abolishing the distinctions between the two writs.

$8_{4}$ Freund, note 83 supra; Freund, Legislative Regulation, c. VIII, Definiteness of Terms (1932). 
The "prior appropriation" rule is sufficiently certain in application to be classed as "definite." The person who first appropriates water for irrigation or other use has the privilege of continuing the use, and the right that others shall not interfere with the exercise of such privilege. Controversy may arise over the meaning of each part of that rule. Thus, is "person" limited to a riparian owner? What is the date of the "appropriation" when years elapse between the drafting of plans and the completion of the dam or the filling of the reservoir? What amounts to a "use"? Does a certain act "interfere" with the privilege? Against whom may the right be acquired? It is clear that this rule is not perfectly definite. However, when the facts are settled in a dispute between two parties who wish to make inconsistent uses of the water in the stream, this rule will eliminate as immaterial many factors, such as: the needs of the parties, the benefits derived from the use, the types of use, the relative sizes of the farms or the frontages along the stream, the location of the lands within or without the watershed, etc. The rule makes the decisions depend upon priority in time of first appropriation, and especially after the various uncertain words have received judicial interpretation, the rule can be applied by different lawyers or judges with considerable uniformity in result. This rule may therefore be classed under the relative term "definite."

The "reasonable use" rule, on the other hand, is not at all certain in its application. In a particular dispute between a lower and an upper riparian owner, neither litigants nor courts will agree as to what use is "reasonable." Because the rule is of such little value in deciding a concrete case, it has disapprovingly been called "vague," or only a "post-decision label." But this is merely emphasizing the disadvantages that must accompany the advantages of an indefinite rule. And perhaps this vagueness has been overemphasized. In deciding the concrete case, the indefinite rule does have value in that it establishes the important point that no one factor or group of factors should determine the decision, but that a just result should be reached on the basis of all the facts without the impediment of a "technical" (i.e., definite) rule.

Thus, the definite rule selects a few facts and provides that when these facts exist or have certain stated characteristics, certain legal results follow. There may be a controversy over the facts, but when that is settled, the definite rule determines the value-judgment to be applied to the case. The extremely indefinite rule, on the contrary, leaves to judicial determination, not only the facts, but also the value-judgment to be placed on them. Most rules of law will lie somewhere between these two extremes, pointing out with more or less definiteness which factors are important 
in making the decision and what relative importance should be placed on each factor.

The same idea may be stated from the point of view of the person or court drafting the rule. What should be the nature of the rule that should settle disputes between riparian owners over the use the upper owner is making of the stream? To be practical, the rule must be a reasonably short sentence. It may be stated in the form of a proposition: "if so and so, then this legal result follows." The "so and so" must not be too long or too complicated, and must therefore prescribe only a very few factors to determine the legal result. These factors vary widely in simplicity and definiteness. If each factor is simple and definite, the result is a definite rule that makes legal liability depend upon the existence or characteristics of only a few facts, ignoring all other facts as being immaterial. If it seems unjust and arbitrary to ignore all but three or four facts, some one or more of the factors may be a word or phrase which loosely represents a complex group of simple facts, ${ }^{85}$ or more commonly, one of the factors may be a complex act to which an epithet is attached which indicates an approval or a disapproval of the way in which the act was done. There are many such epithets in use in legal rules, each indicating that a value-judgment will have to be made by the person applying the rule. These may be called "indefinite" words or phrases. A few in common use are: reasonable, adequate, safe, sufficient, suitable, proper, unreasonable, unfair, unjust, unprofessional, dishonorable, immoral, malicious, excessive, gross, direct, consequential, negligently, nuisance, due process.

With this choice in mind, the rule regarding the rights in the stream may be selected. In one state, each stream is unique: one stream is important for navigation, making it desirable to prohibit dams and diversions. Another is too rapid for navigation, but will furnish power to many mills if no water is diverted. Another can best be used for supplying water for a city or an irrigation project. One must be kept clean for drinking purposes, while, another furnishes ready outlet for sewerage. In spite of our desire for definiteness in law, injustice and uneconomical use would result from the adoption of a definite rule based on only two or three of the characteristics of the stream. The rule of law should not force the court to give undue weight to any one fact, but should lead to a considera-

\footnotetext{
${ }_{85}$ More properly, the factor is usually itself the conclusion of a simpler proposition of law. Tllustrations: he converted the goods; he owes $\$ r, 000$; he was insolvent; he delivered the deed; he was married; he owned the property; he contracted to do this; he made a fraudulent misrepresentation; he was a partner, or agent; he is a citizen of this state; he was appointed and duly qualified. Even without the use of typically indefinite words and phrases, these factors differ greatly in simplicity and definiteness.
} 
tion of all the facts. To reach this result the rule might provide that a riparian owner may make a reasonable, but not an unreasonable, use of the stream.

Another state might face an entirely different situation. The state is new and wishes to attract settlers. The streams are all quite similar, fed by distant mountains and flowing through semi-arid country. Power and navigation are unimportant. Farming is practical only if water is available for irrigation. Settlers will spend money for irrigation ditches and other works only if assured that an owner farther up the stream will not cut off the source of supply, and a lower owner cannot get an injunction against his diversion. Immigrants can be attracted by the promise that the first-comers will get prior rights. Or perhaps of more practical importance, the first-comers, after developing their irrigation projects, have been ready to enforce a claimed priority by gun, bomb and ballot. This situation exists along every stream in the state. ${ }^{86}$ The cases are similar; an indefinite rule is unnecessary. Priority of appropriation alone will furnish a sufficient criterion for determining water rights in that jurisdiction. Because a definite rule based on such priority can be applied so easily and accurately, it will tend to reduce litigation, settle "titles" to such important rights, and furnish the courts with a protection against charges of prejudice and favoritism.

Those two rules applied to rights in streams illustrate the typical differences between definite and indefinite rules. The very definite rule prescribes with certainty the law to be applied upon the proof of a few fairly simple facts. The very indefinite rule leaves the court unhampered to reach what it believes to be the equitable decision in the particular case. Neither has a monopoly on the advantages or the disadvantages, the praise or the condemnation. If the indefinite rule is approved, it is "flexible" and "equitable"; if disapproved, it is "vague." The rule that is "definite" and "certain" to those who favor it becomes "rigid" and "technical" to its opponents. In determining the best rule for a field of the law, two considerations should control the degree of definiteness to be selected. One is the relative importance of the conflicting characteristics of certainty and flexibility. The other is the degree of uniformity in important facts found in the cases within the field-how homogeneous or heterogeneous, stereotyped or unique, the cases are. For an intestacy act, the rules determining heirship should be as definite as possible; for a constitution that is

\footnotetext{
${ }^{86}$ Historically, the rule was first applied in California in a situation that was different but equally stereotyped. See Meng v. Coffey, 67 Neb. 500, 93 N.W. 7I3, 60 L.R.A. 9I0, I08 Am. St. Rep. 697 (1903).
} 
to guide a nation through centuries of change, the important grants and limitations must be extremely indefinite. ${ }^{87}$

\section{B. DEFINITE AND INDEFINITE TERMS IN PLEADING RULES}

The rules of pleading in equity were generally much more flexible than the corresponding ones at common law. "The Spirit of the Code" involved the adoption of some of these indefinite rules. Which ones should be adopted? If some definite rules were to be retained, how should they be worded in the code? What language should be used in prescribing the indefinite rules?

A complete answer to those questions would necessitate a detailed discussion of each present rule and the proposed substitute. I am not prepared or qualified to write the book that would be required for this. I have attempted such an answer in the fields of "parties" and "joinder of causes of action," but even after eliminating some of the difficult problems, such as third party practice and intervention, the answer is so long that it will

${ }_{77}$ While it will not be desirable here to elaborate on other characteristics of the two extreme types of rules, the following propositions are stated, with little or no proof or discussion, in order to suggest the importance of determining what degree of definiteness is desirable for the rule governing a particular case:

a) The definite rule as originally enunciated by court or legislature later proves to be unfair when applied to some unanticipated cases coming within the wording of the rule. Because of this harshness, exceptions are developed for nearly every definite rule. This can be more easily accomplished with a court-made rule than with a statutory rule.

b) The indefinite rule is not inconsistent with a definite rule covering a part of its field. Thus, the right of a riparian owner to take all the water he needs for domestic purposes is a fairly definite rule within the field covered by the "reasonable use" rule. In fact, the whole of law can be stated under the rule "law is reason"; all more definite rules cover parts of that larger field.

c) As cases multiply, the fields formerly covered by indefinite rules are gradually carved into smaller fields, some covered by more definite rules. This is aided by the doctrine of stare decisis.

d) The courts prefer definite rules, in order to avoid charges of favoritism. An important school of political thought has emphasized the necessity of definite legal rules as furnishing the only check on the judiciary in our system of government where the judiciary is the check on the legislative and executive branches of the government.

e) Indefinite words really grant discretion to the courts (subject to review only by higher courts), though the courts attempt to hide this by pretending an indefinite word is definite, by citing previous cases that are identical only in a few of the facts and in the decision desired, or by developing a definite rule for a part of the field covered by the indefinite rule.

f) The important constitutional limitations are generally indefinite.

g) Some rules may superficially appear rather definite, but the cases in practice prove to be borderline ones wherein an indefinite rule is applied, e.g., "interstate commerce" under the present supreme court decisions, and the Sherman Anti-Trust Act after the development of the "rule of reason." See State v. Schaeffer, 96 Ohio St. 215, 230, II 7 N.E. 220, 224 (19I7).

h) Common-law actions containing indefinite concepts, such as "negligently" in case, 
have to appear as a separate law review article. When that is published, ${ }^{88}$ it may constitute a sufficiently detailed answer to the questions as applied to those two fields. For this paper, a sampling will be taken cutting across the field in the other direction; several problems will be mentioned, but there will be no discussion of details and only a general suggestion of the faults in the present rules and the proposals for their correction.

Perhaps it is possible to group the problems roughly together according to the type of reform attempted in the code, and the method adopted for its achievement.

\section{New Indefinite Rules Stated in Misleading Terms.}

There is no doubt but that some of the provisions of the code were framed with the object of prescribing the indefinite equity rule in place of the rigid common-law rule. The best method of reaching this result would seem to be the statement of the rule in clearly indefinite terms. But that was not done in the most important cases.

One such case involves the problem of joinder by the plaintiff of several causes of action against the same defendant. The original writ determined the limits of joinder at common law. While this permitted the joinder of some cases having nothing in common, there was no demand for restricting joinder, as the plaintiff would ordinarily not jeopardize his chance of getting a judgment by confusing the jury with several unrelated matters. But often actions under different writs were so closely related that they could conveniently be tried together. The equity rule permitted joinder when it seemed probable that the two or more causes of action could be more advantageously handled in one suit than in several suits. ${ }^{89}$ This would ordinarily occur when there was a serious dispute regarding an issue that was common to both.

\footnotetext{
"converted" in trover, and "being indebted" in general assumpsit, have furnished the elasticity necessary for much of our growth in law.

i) The fairness of imposing severe penalties, and the success of various methods of enforcing the rules, may vary with the definiteness of the rules.

j) The determination of the value-judgment to be drawn from the facts is generally a legal problem for the court. Under instructions stating an indefinite rule, the jury may be charged with the duty not only of determining the facts, but also of deciding whether or not those facts should give rise to a cause of action. Where a community standard is desired, as in many negligence cases, the courts welcome this chance to shift the problem to the jury. But where property rights are involved, as in the riparian rights cases or in the will contest cases on the issue of lack of sufficient mental capacity, the courts will take from the jury all cases except those very close to the border line.
}

88 To appear in the June number of this Review.

89 Anderson v. Anderson, 293 Ill. 565, I27 N.E. 66r (1920), Hinton, Cases on Equity Pleading 235, 245 (I927). 
It would seem rather simple to draft a rule that would permit joinder leading to trial convenience. Such a rule would have the advantages and the disadvantages of an indefinite rule. But apparently it was felt desirable to hide the indefinite nature of the rule, lest someone would object that it was vague. The rule as adopted permitted joinder where the causes of action were brought to recover "upon claims arising out of the same transaction, or transactions connected with the same subject of action."9o Then came the cases. What was a transaction? What was a subject of action? When were transactions connected with the same subject of action? The terms may not have sounded vague, but they actually were. They had all the disadvantages of indefinite terms, and an additional one that was much more serious: the lawyers and courts were deluded into arguing over the non-technical meaning of those misleading terms instead of considering trial convenience.9r Those vague phrases increased the litigation over this purely procedural point, and caused many undesirable decisions. The results were all bad.

That particular problem can easily be avoided by removing all restrictions on joinder of causes of action between the same parties. This is the modern tendency, ${ }^{92}$ and is safe enough in practice because the decision on joinder is thereby left to the plaintiff who is the person most anxious to keep the trial from becoming too complicated and confused. But the same problems arise under the sections dealing with the joinder of causes of action involving different parties. The equity rule again applied the test of trial convenience. ${ }^{93}$ The codes, attempting to state this rule, made the decision depend upon the interpretation of such provisions as: "all persons having an interest in the subject of the action and in obtaining the judgment demanded," person "who has or claims an interest in the controversy adverse to the plaintiff," and persons "in whom any right to relief in respect of or arising out of the same transaction or series of transactions is alleged to exist." While the text-writers have not been much more successful in stating the "flexible rules" in the indefinite language that will point out the test of trial convenience, ${ }^{94}$ there seems little justification for the failure of the codes and rules to indicate the true nature of the flexible rule. ${ }^{95}$

90 Sec. 484 (9) of the original New York Code. This is omitted from several of the codes.

9x Clark, Code Pleading 308 (I928).

92 Federal Equity Rule 26; III. C.P.A. \& 44, Smith-Hurd's Ill. Rev. Stat. I935, c. IIO, \& 168.

93 Pittsburgh v. Pittsburgh \& L.E. R.R. Co., 263 Pa. St. 294, ro6 Atl. 724 (rgrg).

94 Story, Equity Pleading 76, 83 ff. (6th ed. I857); Clark, Code Pleading 247 (Ig28).

${ }^{95}$ Federal Equity Rule 26 comes very close to a satisfactory test: "or sufficient grounds must appear for uniting the causes of action in order to promote the convenient administra- 


\section{Nere Definite Rules Stated in Misleading Terms.}

Some of the other rules containing misleading terms were possibly intended to be definite rules, or at least definite rules should have been adopted.

Probably the "real party in interest" rule belongs in this group. The nominal plaintiff in an ejectment action was generally a fictitious person. The assignee of a chose in action sued in the name of the assignor. These rules could easily have been changed by a definite rule. Perhaps further changes should be made. The person with the entire beneficial interest might be permitted to sue, though he lacked the "legal title"; at least, a dry trust could be treated as executed, at the option of the sole beneficiary. The code shunned such definite provisions. The action should thereafter be brought in the name of the "real party in interest." Who is the "real party in interest"? Only the person with the legal title? Or he who has the beneficial interest? Or either? Again the terminology of the code gives a false impression of definiteness. A vague expression is used; this time there seems to be no need for indefiniteness. ${ }^{96}$

Another unnecessarily vague rule is perhaps the most famous one in the code: the complaint must contain "a plain and concise statement of the facts, constituting each cause of action, without unnecessary repetition." This was announced in advance by the commissioners as "the key of the reform." Yet it "has proven probably the most unsatisfactory part of their reform." 97 it is just another vague provision. Of course, the fictitious lease, entry and ouster in ejectment, losing and finding in trover, and promise in general assumpsit, are gone; but these fictitious allegations could better have been discarded by definite rules. Except for those fictitious allegations, each statement in each pleading has about as much right to the name "fact" as any other statement. The allegations do vary greatly in degree of detail. The grocer collecting his bill need state little more than that the defendant owes him money for goods, wares and merchandise sold and delivered by the plaintiff to the defendant. On the other hand, a party bringing an action of deceit is not entitled to make a charge of fraud unless he states in much more detail the nature of the misrepresentation; and the person bringing a slander action must hire a good lawyer if he is to have pleadings that will stand the test of the eighteenth cen-

tion of justice." This seems to be a little too indefinite. Rule 37 unfortunately covers the same problem in the typical code terminology.

${ }_{96}^{6}$ The rule takes on a definite appearance in Clark, Code Pleading 97 (I928). See also: Clark and Moore, A New Federal Civil Procedure: II-Pleadings and Parties, 44 Yale L. J. I29I, I3IO ff. (I935).

97 Clark, The Complaint in Code Pleading, 35 Yale I. J. 259, 260 (xg26). 
tury court. The actions vary not only in the detail required of the allegations, but also in the number of allegations required. Thus, probable cause is treated as an affirmative defense in false imprisonment, and need not be denied in the declaration; but in malicious prosecution, an unfavored action, the plaintiff must negative probable cause in order to state a prima facie case.

With such variations in the statements at common law, which requirements are changed by the demand for "facts"? Many of the inconsistencies of the former system could be justified by policy. Even though some could not be, it is hardly reasonable to expect the courts to overthrow all precedents and develop new tests for the degree of detail in each action, when prodded and guided only by the vague word "facts." 98

The rules of this type are doubly bad. As in the joinder cases, an indefinite rule is vaguely stated. But here, even a clearly indefinite rule would not have been desirable. The situations should have been met by definite rules.

\section{Other Changes in Unnecessarily Indefinite Terms.}

In some other cases, it is not certain just what, if any, change was intended by the code provision, but any desired change would call for a definite rather than an indefinite rule.

The problem of pleading "equitable defenses" could have been greatly clarified by a simple rule telling how such matters should be pleaded and what penalty would be imposed for pleading it in the wrong type of instrument. Much difficulty has arisen over the rule permitting the defendant to set up "as many defenses or counterclaims, or both, as he has, whether they are such as were formerly denominated legal or equitable." Should a counterclaim, or an answer, or either, be used to set up these matters which are logically defensive, but historically have been pleaded as causes of action?"9

Perhaps a clearer case of unnecessary ambiguity is to be found in rules which provide that the court "may" permit an amendment, or "need not" do something else. ${ }^{\text {xoo }}$ Where it is merely desired to remove a disability, such a provision is entirely satisfactory. But Rule 166 of the New York Civil Practice Act is a guide for determining when an amendment should be allowed, and when it should not be. For this purpose it is worthless and will lead to all kinds of inconsistencies when applied by different

${ }^{8}$ See Cook, Statements of Fact in Pleading under the Codes, 2I Col. L. Rev. 4I6 (r92I); Isaacs, The Law and the Facts, 22 Col. L. Rev. I (I922).

99 Hinton, Equitable Defenses under Modern Codes, I8 Mich. L. Rev. 7I7 (I920); Cook, Equitable Defenses, 32 Yale L. J. 645 (1923).

${ }^{200}$ E.g., Cahill's New York C.P.A., rule r66, and § ro5. 
courts. The rule should indicate a policy, or a controlling factor, that will help the courts reach more consistent and predictable results. ${ }^{\text {ior }}$

That objection is not answered by stating that the right to amend should be left to the "sound discretion of the court." The decision regarding the privilege of amending is often a vital one; final judgment may depend upon the party's right to win on the merits of the cause of action or defense erroneously pleaded. "The Spirit of the Code" prescribes a decision on the merits. This right may be stated indirectly by a rule permitting an amendment; if this method is adopted, the privilege of amending should be absolute, except for the power of the court to impose terms that will effectively protect the adverse party. At least, this important problem should not be left to the discretion of the court, unguided by any expression of policy. The provisions in the codes which were intended to prevent judgments based on pleading and practice defects, have in the main been loosely drawn, and have not been sufficiently definite to cause the courts to follow "The Spirit of the Code" rather than common-law precedents to the effect that errors were presumed to be prejudicial. ${ }^{\text {02 }}$

\section{Existing Rules in Misleading Terms.}

The last type of misleading rule may be illustrated by the rule governing intervention in federal equity cases. The law of intervention, as developed in many decisions, is rather complicated. There are several different types of cases, with different rules for each type. Certainly the law of intervention cannot be stated in one sentence or one paragraph. The framers of the rules might attack the problem in either of two ways: (I) The cases might be carefully studied and the field "codified" by rather definite rules. This would be a difficult task, and should be attempted only if the field is in need of codification. (2) The present law might be recognized and retained, with no appearance of stating the law or changing it. For this purpose the rule might merely provide: "A person having a right to intervene in any action may be made a party on his petition."

The second paragraph of Federal Equity Rule 37 follows neither of these methods. It stipulates: "Anyone claiming an interest in the litigation may at any time be permitted to assert his right by intervention, but the intervention shall be in subordination to, and in recognition of, the propriety of the main proceeding." What is the effect of that rule? Does it codify the law with respect to intervention? Does "anyone claiming an interest in the litigation" increase or limit the previous right to intervene?

sor Section ro5 (note roo supra) is much more satisfactory in this respect.

${ }^{302}$ Compare: Isaacs, Logic v. Common Sense in Pleading, I6 Mich. L. Rev. 589, 598, note 13 (I9I8); McCaskill, Illinois Practice Act Annotated II3 (1933). See note 4 I supra. 
Does the last part of the sentence change the status of the intervening party?

A court would hardly rely on this statement as affecting the right to intervene. An indefinite rule, with much discretion left to the trial court but with some precedents definitely limiting this discretion, will continue to govern this right. Rule 37 is really a vague one, but it has the illusory appearance of a definite one, and is misleading to the extent that it directs the attention of the court from trial convenience and fairness to an interpretation of the expression "interest in the litigation."

The last part of the rule is equally objectionable. Is the status of an intervening party affected by the statement that he is in a subordinate position? What duties, of obedience or respect, does such a subordinate owe to his superior? The cases indicate that the status of the intervener, and the extent to which the original suit may be distracted by his claim, will vary with the type of case. Again, this rule will cause considerable trouble, and has no justifying asset. ${ }^{\text {roa }}$

Exception may be taken to all these objections on the ground that defects may be found in any statute. But that statement, with its insinuation that an unfair sampling of the code was taken for this criticism, does not constitute a valid defense of the existing codes and rules. The sections that have just been condemned include all the most important sections, and a few less important ones that are typical of the whole.

The sections on trial and appellate court practice were included in the criticism of Part I because many of the rules were unfairly enforced by judgment against the party failing to proceed in the prescribed manner. Perhaps these practice sections are not equally open to this criticism of poor draftsmanship. But the pleading rules contain entirely too many "glittering generalities"-expressions which seem to be definite but which are really extremely vague. This same misleading style is used whether a definite or an indefinite rule is desired.

While no canon can give skill to a draftsman, a real improvement might result from a careful consideration of the degree of definiteness desired for each rule, and the type of expression appropriate for achieving the desired result. Illusory generalities have been used in the strategic parts of present codes and practice acts, with the hope that they would enthrone and preserve "the Spirit of the Code." They have failed. In their place definite terms must be employed when definite rules or amendments are desirable; clearly indefinite terms, despite their patent vagueness, must be

so2s Moore and Levi, Federal Intervention: The Right to Intervene and Reorganization, 45 Yalc L. J. 565 (1936). This article appeared after the present one went to press. 
used in the rules that are to provide flexibility by relying on the sound discretion of the court.

\section{CONCLUSION}

The suggestions herein made will not simplify the work of the committee drafting the new federal rules of procedure. On the contrary, they challenge the idea that the present Federal Equity Rules are satisfactory, or that the new rules can be prepared by the use of scissors and paste pot. Each pleading problem must be examined anew and a sound solution to the problem must be worked out. Appropriate language, with special emphasis on the degree of definiteness, must be selected for stating this solution. In addition, the rule must clearly designate the penalty to be imposed against the party who fails to comply with its requirements, and this penalty must be a reasonable one.

True, such a program requires time for consummation. But the results would be worth the effort. The revisions of the rules of civil procedure in both Germany and Italy have been preconceived as the products of a generation of preparation, drafting, study, criticism and revision, all with the help of the best of local and foreign talent. In each of these countries the work has been underway for over fifteen years. ${ }^{103}$ It is true that such an exhaustive program is apt to lose more from dissipation of energy and enthusiasm than it gains by thoroughness. But the advice of Dean Pound, regarding reform under consideration in Illinois a quarter of a century ago, is even more applicable for our Federal procedural reform today than it was for the situation for which it was given:

From the New York Code of 1848 to the present, the bane of procedural legislation has been hurry. Let us settle the principles carefully and thoroughly. After all, Illinois has one advantage today from her backwardness in procedural reform. The time is ripe for something far better than has ever before been possible. Codes and practice acts have shown us many things to avoid, and we can know what not to do as well as what to do. Illinois has an opportunity, if she will but proceed deliberately and thoroughly, to lead at a time when leadership is much needed..$^{04}$

${ }^{803}$ The work on the reform of civil procedure in Germany started shortly after the beginning of this century in the Ministry of Justice. As a first step, foreign scholars were asked to write treatises on procedure in the several European countries which had recently been active in procedural reform. These are being published under the title Der Zivilprozess der Kulturstaaten. In I920 a committee was appointed to study suggestions and draft proposed rules. Partial reform measures were adopted in 1924 and in 1934 . A complete preliminary draft of proposed rules was published almost ten years ago, and these are still being studied. For a report on this movement up to 1925 , see Stein and Jonas, Die Zivilprozessordnung, v. I, pp. XXIX-XXXI (I2th ed. I925). The present code was the product of I 7 years of study (I859 to 1876 ). Stein, Grundriss des Zivilprozessrechts 49 (I929). A reform program has been under way in Italy since Igrg. The first draft of proposed rules was published over ten years ago, and is now being studied. Foreign criticisms were sought and published in vols. II and III, Annuario di Diritto Comparato I22-232 (I929).

ro4 Pound, Some Principles of Procedural Reform, 4 IIl. I. Rev. 49I, 508 (I9I0). 